\title{
Heat Shock Proteins in Coeliac Disease
}

\author{
Erna Sziksz ${ }^{1,2}$, Leonóra Himer,2, Gábor Veres², Beáta Szebeni1,2, \\ András Aratón ${ }^{2}$ Tivadar Tulassay ${ }^{1,2}$ and Ádám Vannay ${ }^{1,2}$ \\ ${ }^{1}$ Research Group for Paediatrics and Nephrology, \\ Semmelweis University and Hungarian Academy of Sciences, Budapest, \\ ${ }^{2}$ First Department of Paediatrics, Semmelweis University, Budapest, \\ Hungary
}

\section{Introduction}

Coeliac disease is a complex inflammatory disorder of the small intestine with autoimmune features in genetically predisposed individuals and triggered by chronic exposure to gluten of wheat, barley and/or rye (Trynka et al., 2010). The aim of the recent chapter is to introduce and characterize a family of proteins, called heat shock proteins (HSPs), which are known to be key molecules during stress responses (Polla \& Cossarizza, 1996). We will discuss the potential involvement of HSPs in the pathomechanism of coeliac disease based on recent scientific results. We will also refer to some future directions and potential therapeutic intervention.

\subsection{What is coeliac disease?}

Coeliac disease also known as gluten-sensitive enteropathy or nontropical sprue is a digestive disease occurring in genetically susceptible individuals, triggered by dietary gluten and related prolamins, which damage small intestine and interfere with absorption of nutrients (Setty et al., 2008). Gluten and prolamins are present in wheat, rye and barley, but also in some products such as stamp and envelope adhesive, medicines, and vitamins (Rodrigo, 2009). The genetic predisposition has been associated with the major histocompatibility complex region on chromosome 6 p21. More than $90 \%$ of coeliac disease patients express the antigen-presenting molecules human leukocyte antigen-DQ2 and the remaining coeliac patients express DQ8 (Silano et al., 2010; Schuppan et al., 2005). Approximately $1 \%$ of the population is affected by coeliac disease (it remains mostly undiagnosed) (Green, 2005). It is not clear, why the prevalence of coeliac disease increased over the last decades, but similarly to other immune mediated diseases - such as allergy or asthma - this tendency suggests the importance of environmental stress factors besides the genetic predisposition (Rubio-Tapia \& Murray, 2010). In addition, novel and trustful diagnostic marker (tissue transglutaminase) could help to uncover previously undiagnosed cases. Coeliac disease was traditionally considered to be a childhood disease, however, most patients are diagnosed in adulthood (Virta et al., 2009). Coeliac disease often becomes active for the first time after surgery, pregnancy, childbirth, viral infection, emotional or other stress situations (Baldassarre et al., 2008). Concepts/hypothesis such as the hygiene 
hypothesis, perhaps changes in wheat or other cereals may lead to the increased prevalence of coeliac disease. The disease leads to intestinal inflammation, villous atrophy, and crypt hyperplasia of the small intestine (Kaukinen et al, 2010). Furthermore coeliac disease may be associated with various extra-intestinal complications, including isolated iron deficiency anemia (Doganci \& Bozkurt, 2004), bone and skin disease (Maniar et al., 2010; Reunala, 2001), infertility, endocrine and neurologic disorders (Gupta \& Kohli, 2010). Presumed disease is mainly detected by serologic screening for the presence of tissue transglutaminase specific immunglobulin A antibodies, and this should be followed by taking biopsy samples from the small intestine mucosa to establish a definite diagnosis (Rostom et al., 2005). In the pathomechanism of coeliac disease both the adaptive and innate immunity may be involved. The importance of the adaptive immune response to gluten has been well established, but recent observations also suggest the central role for the gluten-induced innate stress response in the pathogenesis of coeliac disease (Jabri \& Sollid, 2006). It is characterized by the presence of lymphocytic infiltration in the epithelial membrane and the lamina propria, and expression of multiple cytokines and signaling proteins (Briani et al., 2008). Recently gluten-free diet is the most effective mode to treat coeliac disease (Fric et al., 2011).

\subsection{How is stress involved in the development and pathomechanism of coeliac disease?}

As mentioned above there is a broad spectrum of environmental, genetic and immunologic factors, which may be involved in the development of coeliac disease. Here we focus on the common effects of different stress factors in the pathogenesis of coeliac disease. Stress is an acute menace to the homeostasis of an organism that may have both a short- and long-term influence on the function of the organs. Stress evokes adaptive responses that serve to defend the stability of the internal environment and to ensure the survival of the organism (Bhatia \& Tandon, 2005). There are several types of stress circumstances: intrinsic, such as genetic and endoplasmic reticulum stress; extrinsic/environmental including heat-, toxin-, radiation-, infection- and injury-induced stress, mechanical and regenerative stress; metabolic stress such as hypoxia-induced, osmotic and oxidative stress. Under normal circumstances the epithelial cells are connected to each other with tight junctions and adherent junctions in the small intestine and in the large bowel as well. These structures of the epithelial cells serve as a barrier and inhibit the transcellular and paracellular permeation of molecules (Turner, 2009). Mechanical, chemical or oxidative stress can impair mucosal integrity (Lewis, 2009), modulate gut motility, epithelial barrier function (John et al., 2011) and inflammatory states (Lyte et al., 2011) and in genetically susceptible persons may lead to the development of coeliac disease (Szaflarska-Poplawska et al., 2011), because incompletely digested peptides of wheat gluten (gliadin and glutenins) and related proteins, as dietary antigens, can be transported across the epithelium and enter into the lamina propria of the small intestine (Alaedini \& Green, 2005). The major processes of the pathogenesis of coeliac disease are shown on Figure 1.

Tissue transglutaminase 2 enzymes, which are the components of endomysium, become activated in the intestinal mucosa (lamina propria) (Schuppan et al., 2009). Transglutaminase 2 is a calcium-dependent enzyme which catalyzes protein cross-linking, polyamination or deamidation at selective glutamine residues (Caccamo et al., 2010) and 


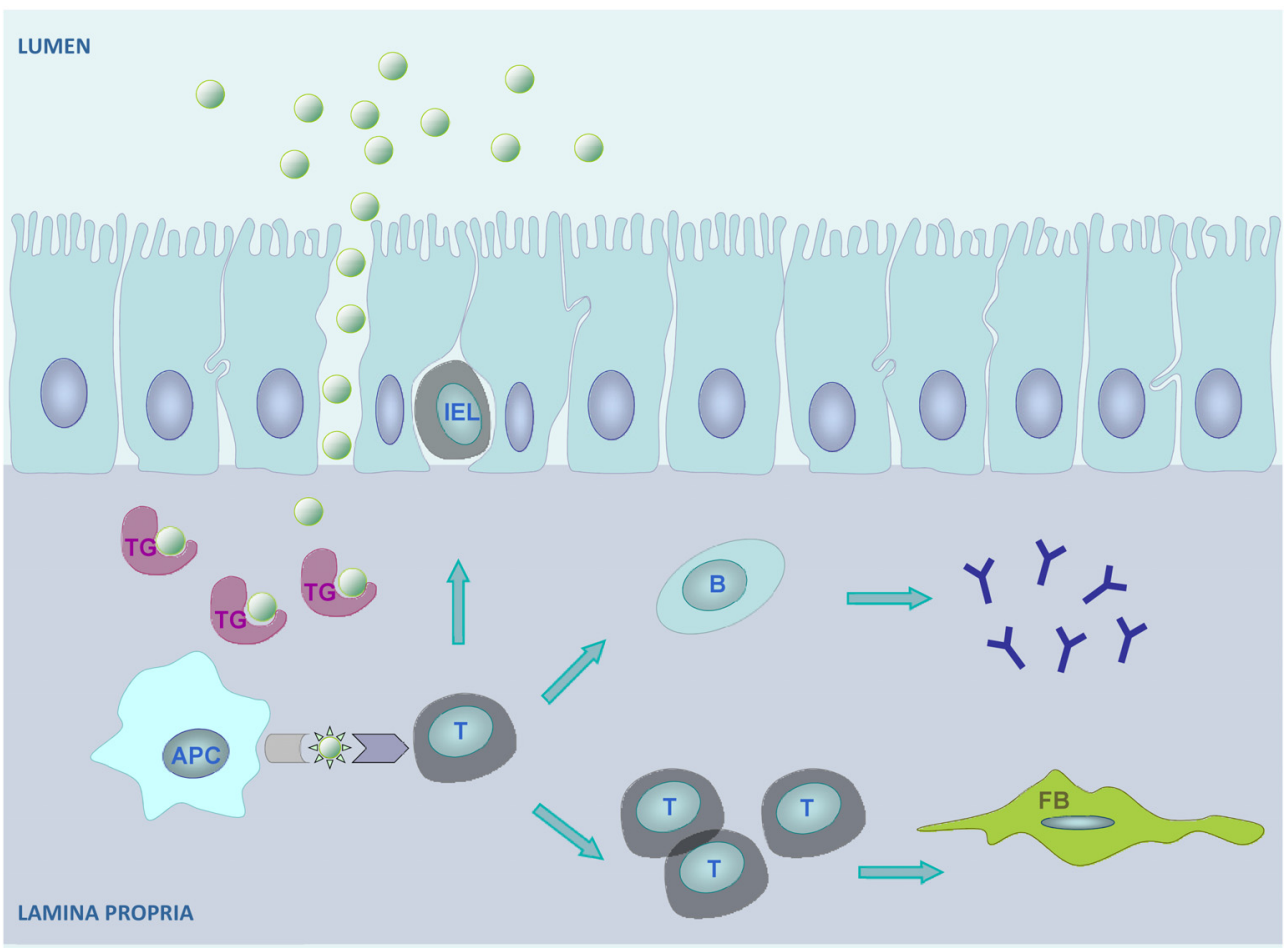

Fig. 1. Major processes of the pathogenesis of coeliac disease. (For explanation see text) Abbreviations: TG: transglutaminase; APC: antigen presenting cell; T: T lymphocyte; B: B lymphocyte; Fb: fibroblast; IEL: intraepithelial lymphocyte

may be involved in different pathological conditions, such as neurodegenerative disorders (Malorni et al., 2008), tumour progression (Chhabra et al., 2009), autoimmune and inflammatory diseases (Elli et al., 2009). Due to its activity neutral glutamine residues of the gluten protein will be deamidated and can be converted into negatively charged glutamic acids, creating epitopes with increased immunostimulatory potential (Briani et al., 2008). Some of the deamidated gliadins may cross-link to transglutaminase and form covalently linked complexes (Alaedini \& Green, 2008; Fleckenstein et al, 2004). Antigen presenting immune cells such as macrophages, dendritic cells and B lymphocytes present the deamidated peptides or complexes through their disease associated human leukocyte antigen-DQ2 and human leukocyte antigen-DQ8 molecules to $\mathrm{CD}^{+} \mathrm{T}$ helper cells in the lamina propria (Qiao et al, 2009). Activated T cells promote B cell maturation, isotype switch, and differentiation into plasma cells producing anti-gluten and antitransglutaminase 2 antibodies (Sollid, 2000). Furthermore activated $\mathrm{T}$ cells express proinflammatory cytokines, such as tumor necrosis factor alpha and interferon gamma, which trigger the release of matrix metalloproteinases by fibroblasts causing epithelial cell damage, degradation of the mucosal matrix and tissue remodeling (Schuppan et al., 2009). Interleukin-15 secreted by epithelial cells in response to gluten exposure activates intraepithelial $\mathrm{CD}^{+} \mathrm{T}$ lymphocytes called cytotoxic $\mathrm{T}$ cells, which can destroy epithelial 
cells, that express stress-induced non-classical major histocompatibility complex class I ligands and human leukocyte antigen E molecules (Briani et al., 2008; Jabri et al., 2005). Gliadin peptides can also directly elicit innate immune responses in macrophages and dendritic cells via pattern recognition receptors such as Toll-like receptor 2 and 4 (Szebeni et al., 2007). Mammalian Toll-like receptors comprise a family of type I transmembrane receptors, which originally recognize conserved pathogen-associated molecular patterns of different microorganisms (Medzhitov, 2001). Activation of Toll-like receptors leads to the upregulation of major histocompatibility complexes, costimulatory molecules and expression of proinflammatory cytokines and chemokines (Takeda et al, 2003). These stressinduced reactions lead to damage of the epithelial cells in the small intestine, which results in increased permeability, loss of barrier function and aggravation of the disease (Sollid \& Jabri, 2005).

\section{Stress inducible proteins: their role and classification}

There are some major key molecules or processes, namely basement membrane degradation, oxidative stress, apoptosis, effect of matrix metalloproteinases and dysregulation of proliferation and differentiation, which are thought to play role in the pathophysiology of coeliac disease (Diosdado et al., 2004), however the exact pathomechanism is not fully understood. Here we focus on stress circumstances, as critical factors in the initiation and pathogenesis of coeliac disease (Lewis \& McKay, 2009). Among several other diseases there are increasing evidences between stress and various gastrointestinal disorders, such as inflammatory bowel disease, irritable bowel syndrome, peptic ulcer disease, gastrointestinal reflux disease (Levenstein et al., 2000; Gué et al., 1997). Organisms must be able to sense and respond rapidly to changes in their environment in order to maintain homeostasis and survive. Therefore as consequence of stress several processes and molecules become activated. Based on the review by Richter K. et al. these proteins can be grouped into classes, namely molecular chaperones (called as HSPs), components of the proteolytic system, RNA/DNA modifying enzymes, metabolic enzymes, regulatory proteins, cell organisatory proteins and transport, detoxifying and membrane-modulating proteins (Richter et al., 2010) (Table 1).

The first discovered stress inducible proteins, called HSPs are recently referred to as "molecular chaperones" (discussed in details later). They are involved in adequate folding of proteins, which means, that these ubiquitous, conserved proteins help other proteins and macromolecules to fold or re-fold and reach their final, native conformation (Papp et al., 2003). Cells are equipped with an efficient surveillance system to selectively eliminate abnormally folded, damaged proteins (Mishra et al., 2009). First with the help of molecular chaperones the cell tries to refold the unfolded proteins (Bukau et al, 2006), but if the refolding is no more possible, the misfolded or irreversibly aggregated proteins will be degraded by the ubiquitin proteasome system (Shang \& Taylor, 2011). In the second class of proteins belong the components of the ubiquitin-proteasome pathway, which is the primary cytosolic proteolytic machinery for the selective degradation of various forms of damaged proteins, so it is an important protein quality control mechanism (Dantuma \& Lindsten, 2010). Degradation of the target protein by ubiquitin proteasome system is a multistep process consisting of activating, conjugating, and ligating enzymes to ensure covalent attachment of multiple molecules of ubiquitin to the target proteins, which finally leads to 


\begin{tabular}{|c|c|c|c|c|}
\hline$\#$ & $\begin{array}{l}\text { Functional protein } \\
\text { class name }\end{array}$ & Function & Examples & Reference \\
\hline 1. & $\begin{array}{l}\text { Molecular } \\
\text { chaperones (HSPs) }\end{array}$ & $\begin{array}{l}\text { Role in protein folding, } \\
\text { decrease the amount of } \\
\text { nonnative proteins and } \\
\text { unwanted intermolecular } \\
\text { interactions }\end{array}$ & $\begin{array}{l}\text { HSP (heat shock } \\
\text { protein) } 60, \text { HSP70, } \\
\text { HSP90 }\end{array}$ & $\begin{array}{l}\text { Tiroli-Cepeda \& } \\
\text { Ramos, } 2011\end{array}$ \\
\hline 2. & $\begin{array}{l}\text { Proteolytic system } \\
\text { components }\end{array}$ & $\begin{array}{l}\text { Help to eliminate misfolded } \\
\text { and irreversibly aggregated } \\
\text { proteins }\end{array}$ & $\begin{array}{l}\text { Lap4 (vacuolar } \\
\text { aminopeptidase), Yps6 } \\
\text { (aspartic protease) }\end{array}$ & $\begin{array}{l}\text { Maupin-Furlow et } \\
\text { al., } 2000\end{array}$ \\
\hline 3. & \begin{tabular}{|l|} 
DNA/RNA \\
modifying enzymes
\end{tabular} & $\begin{array}{l}\text { Necessary to repair DNA } \\
\text { damage and failures, that occur } \\
\text { during stress }\end{array}$ & $\begin{array}{l}\text { DNA helicase, RNAse } \mathrm{p} \\
\text { subunit, topoisomerase }\end{array}$ & $\begin{array}{l}\text {, Jantschitsch \& } \\
\text { Trautinger, 2003; } \\
\text { Biamonti \& Caceres, } \\
2009\end{array}$ \\
\hline 4. & Metabolic enzymes & $\begin{array}{l}\text { Cell energy supply stabilization } \\
\text { and reorganization during and } \\
\text { after stress }\end{array}$ & $\begin{array}{l}\text { acetyl-CoA hydrolase, } \\
\text { NADH ubiquinone } \\
\text { oxidoreductase }\end{array}$ & $\begin{array}{l}\text { Malmendal et al., } \\
2006\end{array}$ \\
\hline 5. & Regulatory proteins & \begin{tabular}{|l|} 
Transcription factors or kinases \\
to regulate stress responses
\end{tabular} & CREB, Fas, HSF & Akerfelt et al., 2007 \\
\hline 6. & $\begin{array}{l}\text { Cell organisatory } \\
\text { proteins }\end{array}$ & $\begin{array}{l}\text { Sustain cellular structures such } \\
\text { as cytoskeleton }\end{array}$ & $\begin{array}{l}\text { claudin, actin, Las } 17 \\
\text { (actin patch protein) }\end{array}$ & Levitsky et al., 2008 \\
\hline 7. & $\begin{array}{l}\text { Transport, } \\
\text { detoxifying, } \\
\text { membrane- } \\
\text { modulating proteins }\end{array}$ & $\begin{array}{l}\text { Stabilization of membrane } \\
\text { structure and function }\end{array}$ & $\begin{array}{l}\text { MarR (antibiotic } \\
\text { resistance), ABC } \\
\text { transporters }\end{array}$ & Vigh et al., 2007 \\
\hline
\end{tabular}

Table 1. Functional classification of proteins induced by heat stress response. For explanations see text. Abbreviations: HSP: heat shock protein; NADH: nicotinamide adenine dinucleotide; CREB: cAMP response element-binding; Fas: FS7-associated cell surface antigen; HSF: heat shock factor; ABC: ATP binding cassette. (Based on review of Richter K. et al., 2010)

degradation of the targeted protein by $26 \mathrm{~S}$ proteasome complex (Glickman \& Ciechanover, 2002). The third functional class of proteins (involved in the response to stress) is the group of DNA/RNA modifying enzymes. They are essential to repair DNA damage that occurs during stress (Jantschitsch \& Trautinger, 2003; Biamonti \& Caceres, 2009). The fourth class is that of metabolic enzymes, which are involved in cell energy supply stabilization and reorganization during and after stress. Malmendal et al. characterized the metabolomic profile of Drosophila melanogaster after heat stress exposure, and found relatively reduced level of some metabolites following shock compared to controls, which were involved in energy metabolism (Malmendal et al., 2006). They described that following heat stress energy storage were decreased in the form of reduced glycogen and fatty acid-like or lipidlike molecules and glucose levels (Malmendal et al., 2006). During stress response regulating proteins such as transcription factors and kinases play also crucial role. They are involved in further initiation of signaling pathways in response to stress or have role in ribosome biogenesis and assembly (Al Refaii \& Alix, 2009). One family of the most important transcription factors involved in stress response is that of heat shock factors (Akerfelt et al., 2007). Heat shock factors play significant role in suppressing protein misfolding in cells by the induction of classical as well as of nonclassical heat shock genes, both of which might be required to maintain protein homeostasis (Fujimoto \& Nakai, 2010). Proteins involved in 
maintenance of cell structure, such as the cytoskeleton, are also significantly induced by stress (Richter et al., 2010). RNA expression and protein levels of the cytoskeletal intermediate filaments, which are essential to the structural integrity of epithelial cells (Sivaramakrishnan et al., 2008), become induced several fold in response to a variety of stress circumstances (Toivola et al., 2010). Initially intermedier filaments were described as molecules, which protect cells and tissues from mechanical stress (Kim \& Coulombe, 2007; Pekny \& Lane, 2007). Due to their special properties namely that their filaments can stretch 3 times their initial length before breaking, intermedier filaments are unique among cytoskeletal proteins (Wagner et al, 2007). The seventh functional group comprises upregulated transport, detoxifying and membrane-modulating proteins (Richter K. et al., 2010). The major role of these proteins is the stabilization of the membrane and preservation of its original function (Welker et al., 2010). Stress induces alterations in the lipid phase of membranes and lipids are known to influence the distribution of proteins within membranes (Vigh et al., 2007). It was also described, that stress stimuli alter the gene expression of multidrug resistance gene 1, which codes an ATP-dependent membranebound transporter called P-glycoprotein (Sharom, 2008). Transporters, such as members of ATP-binding cassette-superfamily are multidrug efflux pumps, play important role in cell protection against harmful chemicals, toxic xenobiotics and endogenous metabolites and they are also involved in the cellular response against stress (Sukhai \& Piquette-Miller, 2000). It has been reported a direct correlation between multidrug resistance gene 1 and heat shock response, and basal activity of the multidrug resistance gene 1 promoter requires heat shock factor-mediated transactivation (Kim et al., 1997). Our present study provides an overview about functional groups of proteins potentially involved in stress response. Hereinafter we will focus especially on heat shock proteins commonly referred to as "molecular chaperones"(Ellis et al., 1989).

\section{What are heat shock proteins?}

Temperatures above the optimum may sensed as heat stress by living organisms, which disturbs cellular homeostasis and can lead to severe retardation in growth and development, and even to death (Baniwal et al., 2004). It has been shown, that cells response to heat stress by increased expression of heat stress proteins (Stetler et al., 2010). HSPs - also referred to as extrinsic chaperones or "molecular chaperones" - are a suite of highly conserved proteins with various molecular weights, which are produced in all organisms, when those are exposed to cellular stress (Welch, 1993). The discovery of HSPs started in the early 1960s (Ritossa, 1962). Ritossa et al. observed different puffing pattern of the chromosomes in Drosophila melanogaster after shifting the incubator temperature (Ritossa, 1996). Later these puffs were found to code proteins, which were identified as HSPs (Moran et al., 1978). When eukaryotic cells were exposed to temperatures $5-15{ }^{\circ} \mathrm{C}$ above their optimum for growth, they responded also by induction of HSPs (DiDomenico et al., 1982). These molecules were found also in prokaryotes and other eukaryotes (Lemaux et al., 1978; Carper et al., 1987; Kelley \& Schlesinger, 1978; Timperio et al., 2008). HSPs are evolutionally highly conserved proteins indicating that heat shock response may be universal mechanism (Richter et al., 2010). Early on, researchers suggested that HSPs function as molecular chaperones mediating the folding and assembly of polypeptides and their translocation across the intracellular membranes (Burel et al., 1992). HSPs are also involved in protein degradation as essential components of the ubiquitin-dependent degradative pathway 
(Morandi et al., 1989). The HSP chaperone machinery may stabilize the target protein to degradation by the ubiquitin-proteasome pathway of proteolysis (Pratt et al., 2004). These functions of HSPs are important during cell repair process after damage. Generally there are two major groups of HSPs, constitutive, which are continually present in the cell, and inducible HSPs (Petrof et al., 2004). HSPs are rapidly induced by a variety of cellular stressors, such as heat, UV light, or cytotoxic agents (Rajaiah \& Moudgil, 2009; Aufricht, 2004), ischaemia-reperfusion injury, oxidative stress and nutritional stress (Akerfelt et al, 2010). Recently our knowledge about their roles have been expanded, including their involvement in the modulation of immune responses (Hauet-Broere et al., 2006; Johnson \& Fleshner, 2006), autoimmunity (Rajaiah \& Moudgil, 2009), cell signaling (Csermely et al., 2007), cell proliferation (Pechan, 1991), and apoptosis (Padmini \& Lavanya, 2011). The expression of HSPs has been reported in several tissues and cell types, including heart (Ghayour-Mobarhan, 2009), brain (Stetler, 2010), muscle (Geiger \& Gupte, 2011), lung (Wong \& Wispé, 1997), kidney (Kelly, 2005), liver (Tashiro, 2009) and intestinum (Asano et al., 2009). It is also known, that HSPs are overexpressed in a wide range of human cancers and are implicated in tumour cell proliferation, differentiation, invasion, metastasis, death, and recognition by the immune system (Ciocca \& Calderwood, 2005). HSPs can be classified into five major families, namely HSP60s, HSP70s, HSP90s, HSP100s and small HSPs (Richter et al., 2010; Roberts et al., 2010) based on their molecular weight. There are also some not ubiquitous HSPs, for example redox-regulated chaperon HSP33, which can not be ranked into these classical groups (Graf \& Jakob, 2002). Major families of HSPs can be seen on Table 2.

\begin{tabular}{|c|c|c|c|c|}
\hline \# & HSP family & $\begin{array}{c}\text { Subunit } \\
\text { molecular } \\
\text { mass }\end{array}$ & Example members & Cellular localization \\
\hline 1. & HSP100 & $80-110 \mathrm{kDa}$ & HSP100, HSP104 & $\begin{array}{l}\text { cytoplasm, nucleus, mitochondia, } \\
\text { plasma membrane }\end{array}$ \\
\hline 2. & HSP90 & 82-96 kDa & $\begin{array}{c}\text { HSP90a (inducible) } \\
\text { HSP90 } \beta\end{array}$ & $\begin{array}{l}\text { cytoplasm, nucleus, mitochondria, } \\
\text { endoplasmic reticulum }\end{array}$ \\
\hline 3. & HSP70 & 67-76 kDa & $\begin{array}{l}\text { HSP70, HSP72, } \\
\text { HSP73, HSP80 }\end{array}$ & $\begin{array}{c}\text { cytoplasm, nucleus, mitochondria, } \\
\text { endoplasmic reticulum, lysosomes and } \\
\text { extracellular compartments }\end{array}$ \\
\hline 4. & HSP60 & $58-65 \mathrm{kDa}$ & HSP60, HSP65 & mitochondria \\
\hline 5. & small HSPs & $8-40 \mathrm{kDa}$ & $\begin{array}{l}\text { alphaB-crystallin, } \\
\text { HSP25, HSP27, } \\
\text { ubiquitin }\end{array}$ & cytoplasm, nucleus \\
\hline 6. & $\begin{array}{l}\text { Others } \\
\text { (not } \\
\text { ubiquitous) }\end{array}$ & various & HSP33 & various \\
\hline
\end{tabular}

Table 2. Major families of HSPs. For explanations see text. (Based on review of Roberts et al., 2010 and Otaka et al., 2006)

\subsection{HSP100 family}

The HSP100 proteins belong to the superfamily of AAA (ATPase associated with various cellular activities) + domain-containing ATPases (Mayer, 2010). They are localized to 
different subcellular compartments, such as cytoplasm, nucleus, mitochondria and plasma membrane (Singh \& Grover, 2010). Interestingly HSP100 proteins and also their homologues are absent in Archaea (Large et al., 2009), but they are found in Bacteria and Eukaryotes (Barends et al, 2010). Main function of HSP100 proteins is that they protect organisms under extreme stress conditions. It was demonstrated on heat-shocked yeast that their survival is significantly reduced in the absence of HSP100 protein (Schirmer et al., 1996). HSP100 molecules function as chaperones in an ATP-dependent fashion leading either to the renaturation or proteolytic degradation of individual proteins (Parsell \& Lindquist, 1993; Liang \& MacRae, 1997). They are important components of the protein quality control system controlling the intracellular levels of global regulatory proteins (Maurizi \& Xia, 2004). It was demonstrated, that HSP104, a member of HSP100 family collaborates with the HSP70 chaperone systems to reactivate stress-denatured proteins from aggregates, which mechanism is crucial for the survival of cells during severe stress (Miot et al., 2011).

\subsection{HSP90 family}

Members of the $90 \mathrm{kDa}$ heat shock proteins (HSP90) family are expressed in various organisms ranging from prokaryotes to eukaryotes (Pearl \& Prodromou, 2006). They are one of the most highly abundant constitutively expressed proteins, comprising $1-2 \%$ of cellular proteins. HSP90 proteins are involved in various cellular processes, such as controlling of cell proliferation, differentiation and apoptosis and their expression increases markedly during stress (Sreedhar et al., 2004; Liang \& MacRae, 1997). Eukaryotes require a functional cytoplasmic HSP90 for their viability: these proteins have role in the folding of a set of cell regulatory proteins and in the re-folding of stress-denatured polypeptides (Obermann et al., 1998; Borkovich et al., 1989). HSP90 proteins are ATP-dependent chaperones and the chaperone machine is driven by the hydrolysis of ATP and ADP/ATP nucleotide exchange. This ATP hydrolysis is coupled to conformation changes of HSP90s, which facilitate target protein folding and maturation (Hao et al, 2010). Recently several HSP90 members have been identified in mammalian cells, including the two major cytoplasmic homologues, the inducible HSP90-alpha and the constitutive HSP90-beta, the glucose-regulated protein 94 in the endoplasmic reticulum, and tumor necrosis factor receptor-associated protein 1 in the mitochondrial matrix (Stetler et al., 2010). Interestingly the bacterial homologue of HSP90 called HtpG is dispensable under non-heat stress conditions (Thomas \& Baneyx, 1998). HSP90s contains nine alpha-helices and eight anti-parallel beta pleated sheets, which combine to form several alpha/beta sandwiches. HSP90 chaperones exist as obligate homodimers, and each monomer consist of an N-terminal regulatory domain, a nonconserved and dispensable charged region, a middle domain, and a C-terminal dimerization domain (Dollins et al., 2007).

A recent study demonstrates that inhibition of HSP90s abrogates the protective effect of bone marrow stromal cells, inhibits angiogenesis and osteoclastogenesis and a HSP90 inhibitor called tanespimycin is able to reduce tumour cell survival in vitro (Richardson et al., 2011). Because HSP90 chaperones play essential housekeeping functions and may be involved in a broad range of processes from signal transduction to immune responses, inhibitors may be promising for novel therapies (Sharp \& Workman, 2006). 


\subsection{HSP70 family}

$70 \mathrm{kDa}$ heat shock proteins (HSP70s) are the major components of the network of molecular chaperones, which are ubiquitously expressed, highly conserved and may be involved in a wide range of folding processes such as modulating polypeptide folding, degradation and translocation across membranes, as well as protein-protein interactions (Ryan \& Pfanner, 2001). The HSP70 family is a most widely studied group of chaperones and comprises at least 13 related proteins expressed constitutively or induced by stress response and exert important cellular housekeeping functions (Daugaard et al., 2007). They can be found in cytoplasm, nucleus, mitochondria, endoplasmic reticulum, lysosomes and extracellular compartments (Stetler et al., 2010). While certain family members, such as HSP73 also known as heat shock cognate 70 is constitutively expressed in the cytosol, transcription of HSP72 is highly responsive to stress (Evans et al., 2010). HSP70 chaperones operate by an ATP dependent manner, namely their polypeptide binding and release capacity is driven by ATP. Various nucleotide exchange factors and co-chaperones (for example the so called DnaJ proteins, which associate with HSP70s and may control their nucleotide turnover (Laufen et al., 1999)) may promote the HSP70 ATPase cycle (Young, 2010). HSP70s may exert important cytoprotective functions in gastric and colonic mucosa (Odashima et al., 2002; 2006).

\subsection{HSP60 family}

A special group of chaperones and comolecules exist in the organisms, which is involved in mitochondrial protein folding. Such proteins are the members of the HSP60 family also called as chaperonins. HSP60s are essential for the health and maintenance of mitochondrial function, as well as for proper mitochondrial biogenesis (Stetler et al, 2010). Although the majority of HSP60 proteins can be found in the mitochondria, $15-20 \%$ of them is located extramitochondrially (in the cytosol, on the cell surface or in the extracellular space) (Soltys \& Gupta, 1996; Pfister et al., 2005). In the animal model of transient global ishaemia, HSP60s can be induced during stress (Truettner et al., 2009). Kuwabara et al. also have found that HSP60s are specifically induced in rat colonic mucosa after 5-hydroxytryptamine-induced ischaemia and it may have cytoprotective effects (Kuwabara et al., 1994). HSP60 proteins also have immunomodulatory functions, because they are activator of Toll-like receptor 4 signaling in macrophages and dendritic cells and also regulate the activity of effector T cells and regulatory T cells via innate Toll-like receptor 2 signaling. It is proposed that HSP60s can serve as biomarkers to monitor the immune status of the individual, providing a potential to modulate immunity for therapeutic purposes in diseases such as in rheumatoid arthritis and type I diabetes (Quintana \& Cohen, 2011).

\subsection{Small HSPs}

The family of small HSPs (sHSPs) is the less conserved family of molecular chaperones. Their only common characteristics is the conserved alpha-crystallin or HSP20 core domain (Richter et al., 2010) named according to its discovery in alpha-crystallin, a highly abundant protein in the vertebrate eye lens (Horwitz, 1992). sHPSs have general importance, they are present in Archaea, Bacteria, and Eukarya, but there is a broad variation of primary sequences within the superfamily and different organisms (Kriehuber et al, 2010). sHSPs are ATP-independent chaperones, which forms large oligomers containing often more than 20 
monomers (Van Montfort et al., 2001). Recent evidences suggest that sHSPs maintain protein homeostasis by binding proteins in non-native conformations, thereby preventing substrate aggregation (Haslbeck et al., 2005). They are also associated with a variety of severe diseases (e.g., myopathies, dystrophies, cataracts, Alzheimer's or other amyloidal diseases, and diverse cancers) and their expression is enhanced under environmental stress conditions such as elevated temperature or exposure to heavy metals or arsenate (Sun \& MacRae, 2005; Haslbeck et al., 2005). Major family members alphaB-crystallin, HSP25 and HSP27 might be involved in the prevention of apoptosis and cell protection against heat shock and oxidative stress, they can stabilize microfilaments (Arrigo, 2007). Modulation of the expression and activities of HSP27 and alphaB-crystallin may have therapeutic potential in the future (Arrigo et al., 2007). Also ubiquitin, a small protein weighting $8 \mathrm{kD}$, belongs to the family of HSPs and it is involved in nonlysosomal protein degradation, which is an important pathway of proteolysis (Kiang, 2004; Heo \&Rutter, 2011; von Mikecz et al., 2008).

\section{Regulation of the HSPs}

As mentioned above, cellular events, which lead to protein unfolding or denaturation (such as elevated temperature, oxidative stress and metabolic disturbances) can activate heat shock response, which leads to the upregulation of HSPs (Noble et al., 2008). Specific transcription factors play a key role in these processes: transcription factor sigma 32 in prokaryotic cells (Rodriguez et al., 2008) and heat shock factor 1 in eukaryotic cells (Anckar \& Sistonen, 2007). However sigma 32 and heat shock factor 1 are not related in their sequence and structure, they share common mechanistic properties leading to HSP overexpression (Richter et al., 2010). In prokaryotes, for example in Escherichia Coli there are a HSP70 and a HSP40 chaperone homologes called DnaK and DnaJ, respectively, which normally form a complex with the transcription factor sigma 32. Thereby the bound sigma 32 , which is an alternative subunit of the bacterial RNA polymerase, remains in inactive state and will be degraded by specific AAA (ATPase associated with various cellular activities) proteases called $\mathrm{FtsH}$ metalloproteases. Under normal circumstances this mechanism results in reduced intracellular level of transcription factor sigma 32, keeping the heat shock genes untranscribed (Rodriguez et al., 2008). During stress the protein homeostasis is disturbed, the number of unfolded proteins is increased, which then bind to DnaK and DnaJ chaperone molecules. Until these chaperones are in complex with unfolded proteins, they are no more able to bind the sigma 32 transcription factor, which becomes activated. Activated sigma 32 binds to RNA polymerase and replaces the normal regulatory o70 subunit and stimulates the transcription of heat shock genes. Similarly to sigma 32 in prokaryotes, in eukaryotes the transcription factor heat shock factor 1 forms complex with HSP70 and HSP40 proteins, which keep it in inactive form inhibiting its function. But compared to the prokaryotes the function of the heat shock factor 1 regulatory system is much more complex, because multimerization, phosphorilation and numerous posttranscriptional modifications might be involved in the mechanism (Prahlad \& Morimoto, 2009). Under stress circumstances the HSPs, also HSP70 and HSP40 bind to unfolded proteins losing their ability to form complex with heat shock factor 1 , which then leads to the release of heat shock factor 1 monomers. After trimerization heat shock factor 1 is transported into the nucleus and becomes hyperphosphorylated by kinases at multiple sites within its regulatory domain (Holmberg et al., 2001). Heat shock factor 1 binds to heatshock elements found in the promoter regions of its target HSP genes, which finally leads to the transcription of heat shock genes (Figure 2). 


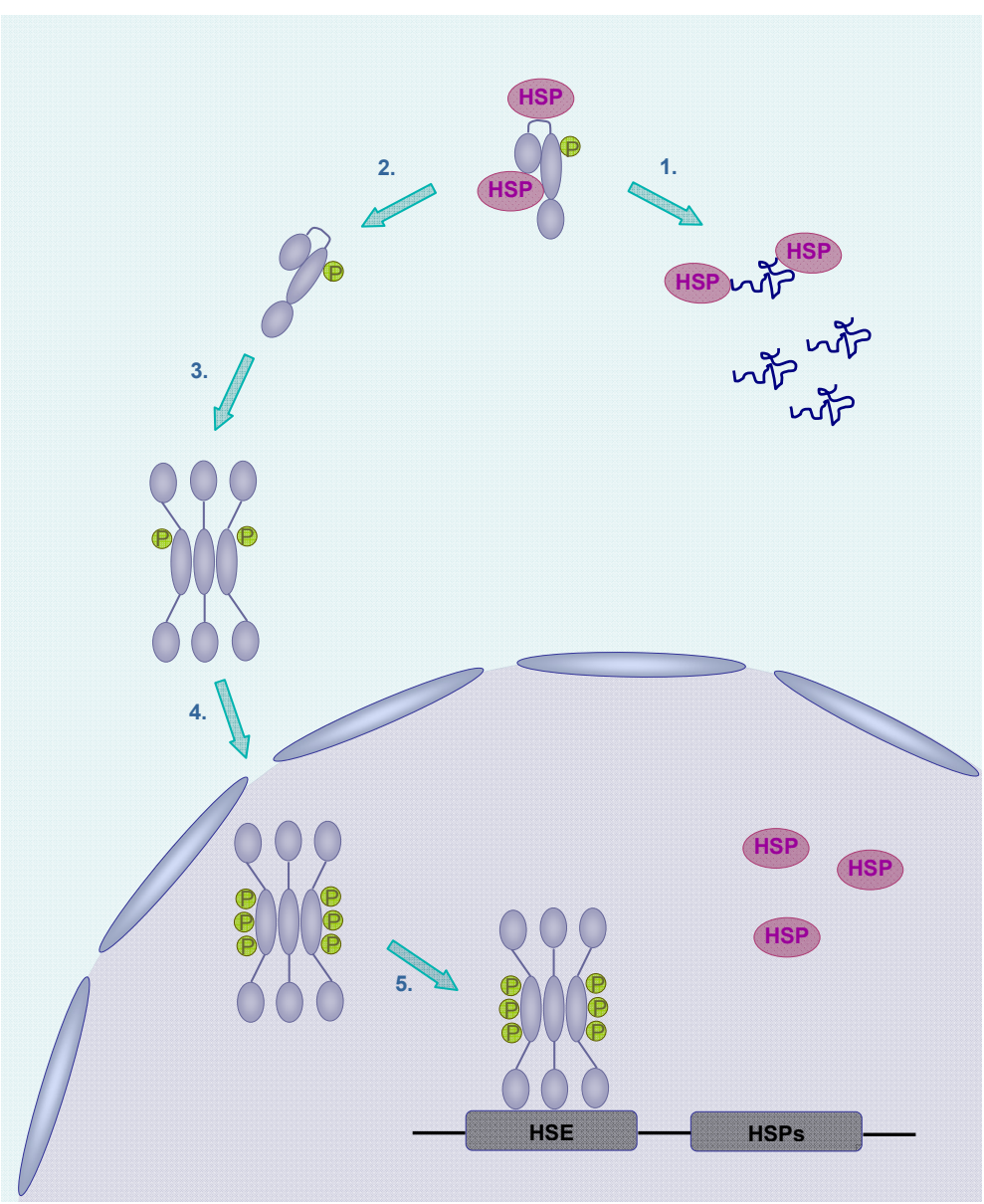

Fig. 2. Regulation of the heat shock response in eukaryotes. Under normal circumstances HSPs are in complex with the transcription factor heat shock factor 1. Under stress HSPs bind to unfolded proteins (1.) losing their ability to form complex with heat shock factor 1 , therefore leading to the release of heat shock factor 1 monomers (2.). After trimerization (3.) heat shock factor 1 is transported into the nucleus and becomes hyperphosphorylated (4.). Heat shock factor 1 then binds to the HSE in the promoter regions of target HSP genes (5.). This process leads to the transcription of HSPs. Abbreviations: HSP: heat shock protein; P: phosphorylation; HSF1: heat shock factor 1; HSE: heat-shock elements

On the other hand the formation of HSP-heat shock factor complex suppresses heat shock factor production maintaining a negative feed-back regulatory system. Furthermore heat shock factor 1 may be inducibly acetylated at a specific residue, which regulates negatively its DNA binding activity (Westerheid et al., 2009). Heat shock factor binding protein 1 has been reported to be a negative regulator of the heat shock response, because heat shock factor binding protein 1 binds specifically the active trimeric form of heat shock factor1, thus inhibiting its activity (Liu et al, 2009). 


\section{Molecular functions of HSPs with special focus on coeliac disease}

In this part we introduce the major molecular functions of HSPs in those processes, which may be also involved in the pathogenesis of coeliac disease, such as oxidative stress, immune response and inflammation, apoptosis and mucosal damage.

\subsection{Oxidative stress}

Different chemical and environmental stressors often act by induction of oxidative damage in the cells (Limón-Pacheco \& Gonsebatt, 2009). In this process reactive oxygen species play a key role. Reactive oxygen species are generated continuously during the respiration process, and their level is markedly elevated by a range of different stress conditions causing oxidative deterioration of proteins, lipids and DNA (Avery, 2011). When production of reactive oxygen species exceeds the capacity of cellular antioxidant defenses to remove these toxic species, it is referred as oxidative stress and together with decreased reductive potential it may induce cell damage or death (Rivabene et al., 1999). It has been assumed that oxidative stress plays an important role in the development of celiac disease, because gliadin can induce oxidative stress responses (Diosdado et al., 2005). Gluten peptides could enhance the mRNA expression of the inducible form of nitric oxide synthase in the small intestine, (van Straaten et al., 1999). Increased inducible nitric oxide synthase and nitric oxide levels contribute to subsequent mucosal damage by promoting the generation of peroxynitrite and free-radicals and can play a role in the mechanism leading to villous atrophy in coeliac disease (Murray et al., 2002). Levels and activity of antioxidant enzymes epoxide hydrolases and glutathione peroxidases and other antioxidants, such as a-tocopherol and lipoproteins (cholesterol and apolipoproteins), which major biological role is the protection of the organism from oxidative damage, were reduced in biopsies taken from patients with coeliac disease (Stojiljković et al., 2007; Odetti et al., 1998). In these processes HSPs may be involved in several ways. Oxygen free radicals, such as superoxide can be an inducer of HSPs (Omar \& Pappolla, 1993). HSP32, also known as heme oxygenase- 1 enzyme participates in the cell defense against oxidative stress by degrading heme to vasoactive carbon monoxide, free iron, and to potent antioxidant biliverdin (Aztatzi-Santillán et al., 2010). HSP60 plays a role in protecting small intestinal mucosal cells from $\mathrm{H}_{2} \mathrm{O}_{2}$-induced cell injury by enhancing the cytoprotective function of small intestinal epithelial cells (Takada et al., 2010). After hemorrhage the inducible form of HSP70 specifically couples to inducible nitric oxide synthase and its transcription factor called Krueppel-like factor 6, which has been demonstrated using immunoprecipitation and immunoblotting analysis (Kiang, 2004). Bellmann et al. found, that HSP70 overexpressing fibrosarcoma cells produced two to three times more nitric oxide than control cells after treatment with interleukin- $1 \beta$ or a combination of lipopolisacharide and interferon gamma- $\gamma$. This HSP70mediated increase of nitric oxide production was accompanied by an enhanced transcription of the inducible nitric oxide synthase gene and an increased accumulation of inducible nitric oxide synthase mRNA and protein. This phenomenon may be specific to HSP70, because overexpression of other HSPs, such as HSP27 does not elevate the levels of nitric oxide. HSP70 can modulate the cellular response to cytokines by acting on signaling elements upstream of p38, which acts as an enhancing factor in the activation of inducible nitric oxide synthase (Bellmann et al., 2000). Furthermore, induction of HSP70s protects intestinal epithelial cells against oxidant injury by preserving the integrity of the actin cytoskeleton and cell-cell contact (see detailed in part 5.4.) (Musch et al., 1999). HSP90 was reported to form a complex with 
endothelial nitric oxide synthase to activate it, which resulted in elevated nitric oxide levels of cardiac cells in vitro, leading to downregulation of $\mathrm{O}_{2}$ consumption in heat-shocked cells and to subsequent attenuation of cellular respiration (Ilang et al., 2004). HSP90 also mediates cytoprotection against chemical hypoxia-induced injury via antioxidant and $\mathrm{H}_{2} \mathrm{~S}$-induced antiapoptotic effects (Chen et al., 2010).

\subsection{Inflammation}

Gluten-derived peptides can activate a harmful immune response in the lamina propria of genetically predisposed individuals (Schuppan, 2000). Antigen presentation of glutenderived peptides to $\mathrm{T}$ cells by antigen presenting cells, such as macrophages and dendritic cells, play a pivotal role in the pathogenesis of coeliac disease. Stimulated CD4+ T helper type 1 cells through release of $\mathrm{T}$ helper 1-type cytokines activate other immune cells, and therefore they have central role in controlling the immune response to gluten that causes the immunopathology of coeliac disease (Di Sabatino et al., 2007). HSPs (such as HSP60, HSP90), which can bind to peptides, are also able to induce immune response. They play important role in antigen presentation and activation of lymphocytes, macrophages and dendritic cells ( $\mathrm{Li}$ et al., 2002). If the cell is damaged, the HSP-peptide complexes appear in the extracellular space and bind to certain surface molecules or receptors (such as to Tolllike receptor 2 and Toll-like receptor 4) of antigen presenting cells, which take up these complexes by receptor endocytosis (Binder et al., 2004). This process leads to antigen presentation by major histocompatibility complex molecules to lymphocytes and finally to the activation of T cell pathway (,Suto \& Srivastava, 1995; Dudeja et al., 2009). HSPs stimulate the production of inflammatory cytokines such as tumor necrosis factor alpha, interleukin-1, interleukin-6, interleukin-12 and C-C chemokines by monocytes, macrophages and dendritic cells (Tsan \& Gao, 2009). These effects are mediated by the CD14/Toll-like receptor 2 and Toll-like receptor 4 complex leading to the activation of mitogen-activated protein kinase signaling pathway and nuclear factor kappa-light-chain-enhancer of activated B cells (Asea et al., 2000). HSP60 induces the maturation of dendritic cells and stimulates their activation more rapidly than lipopolisacharide and elicits a T helper type 1promoting phenotype (Flohé et al., 2003). Furthermore HSPs contribute to the proliferation and activation of natural killer cells (Multhoff, 2009), which may be involved in coeliac disease due to the interaction between their natural killer group 2 member D activating receptors and major histocompatibility complex class I polypeptide-related sequence A molecules expressed on epithelial cells (Gianfrani et al., 2005). The natural killer group 2 member D/ major histocompatibility complex class I polypeptide-related sequence A interaction may have a pivotal role in the activation of intraepithelial immune cells and development of villous atrophy during coeliac disease (Hüe et al., 2004). Since Toll-like receptors can serve as receptors of HSPs (Tsan \& Gao, 2004; Asea, 2008) and their activation leads to elevated expression of proinflammatory cytokines and chemokines, in this manner HSPs may be involved in the pathomechanism of coeliac disease (Takeda et al., 2003). Due to their cytokine-like effects, HSPs may serve as "danger signals" for the immune system at sites of tissue injury (Osterloh \& Breloer, 2008).

\subsection{Apoptosis}

Apoptosis or programmed cell death is essential to the maintenance of the intestinal epithelial functions, because it is involved in the normal enterocyte turnover. Under 
physiological conditions apoptotic cells of the small bowel are restricted to the tips of the villous and are replaced by equal number of proliferating immature crypt cells (Watson, 1995). Increased apoptosis of enterocytes is one of the major mechanisms responsible for villous atrophy in coeliac disease. Apoptosis in coeliac disease may be caused directly by the toxic domains of gliadin peptides or it is mediated by intraepithelial and lamina propria lymphocytes (Di Sabatino et al., 2001). Digested wheat gliadin peptides induce apoptosis by the FS7-associated cell surface antigen (Fas) mediated apoptotic pathway. The ligand of Fas is a cell surface molecule, which belongs to the tumor necrosis factor family and binds to the Fas receptor and induce apoptosis of Fas-bearing cells (Ehrenschwender \& Wajant, 2009). Fas receptor is widely expressed by many cell types, including also enterocytes. Fas was found on most enterocytes isolated from biopsies of patients with coeliac disease, and mononuclear cells of the lamina propria were shown to expressed Fas ligand (Ciccocioppo et al., 2001). Giovanni et al. found increased Fas and Fas ligand mRNA expression in coeliac disease, and this gliadin-induced apoptosis could be blocked by Fas cascade inhibiting agents and neutralizing antibodies (Giovannini et al., 2003). HSPs are also involved in cell death processes, because they may exert anti-apoptotic effects (Dudeja et al, 2009). Fas-Fas ligand ligation induces the binding of heat shock factor 1 to the DNA and increases the production of HSP72 and HSP72-induced chemokines, which than promote cell survival (Choi et al., 2011). HSP70 can inhibit not only the death receptor-mediated extrinsic, but also intrinsic apoptotic pathways, which are initiated by intracellular stress signals and regulated by mitochondrial proteins (Dudeja et al., 2009). During heat-induced apoptosis HSP70 prevents the formation of pores in the mitochondrial membrane by inhibiting the translocation of Bax - a proapoptotic Bcl-2 family member - into the mitochondria and prevents cytochrome c release (Stankiewicz et al., 2005). After inhibition of HSP70, cytochrome $\mathrm{c}$ appears in the cytosol released from the mitochondria, which results in the stimulation of caspase- 9 and caspase- 3 leading to the activation of apoptotic protease cascade and finally to cell death (Li et al., 1997). HSP70 can modulate the calcium signaling, which also has a major role in the regulation of apoptosis (Rizzuto et al., 2003; Creagh et al., 2000). Furthermore, HSP70 has been demonstrated to be a natural inhibitor of cJun Nterminal kinase (Park et al., 2001), which through the induction of Fas ligand promotes an early apoptotic pathway initiated by heat shock (Volloch et al., 2000). Thereby HSP70 may modulate stress-activated signaling, because blocking of cJun N-terminal kinase appears to be involved in the protection against caspase-dependent apoptosis (Gabai et al., 2000). HSP70 also prevent the release of lysosomal enzymes into the cytosol by inhibiting lysosomal membrane permeabilization and therefore stabilizing the lysosomes (GyrdHansen et al., 2004). In contrast to other HSPs, the role of HSP60 during apoptosis is controversial. Recent reports suggest, that HSP60 may have an antiapoptotic effect, but early studies refer to its pro-apoptotic function, because it may facilitate the activation of caspase 3 (Xanthoudakis et al., 1999). However, recently HSP60 has been described as a novel regulator of mitochondrial permeability transition, which contributes to a cytoprotective chaperone network (Ghosh et al., 2010).

\subsection{Mucosal damage}

A critical function of the intestinal mucosa is to form a barrier that separates luminal contents from the underlying interstitium. Integrity of the intestinal barrier is essential for maintaining health and preventing tissue injury. All the above mentioned processes (such as 
oxidative stress, inflammation and enhanced epithelial cell apoptosis) lead finally to mucosal damage, loss of epithelial barrier function and therefore increased mucosal permeability (Farhadi et al., 2003). Integrity of the epithelial barrier is determined by an apical junctional complex that is composed of tight junction and adherens junction (Bruewer et al., 2006). In patients with inflammatory bowel disease the level of key tight junction (occludin, junctional adhesion molecule, zonula occludens 1, claudin 1) and adherens junction (E-cadherin, beta-catenin) proteins reduced or disappeared from the intercellular junctions resulting in the loss of barrier function (Ivanov et al., 2004). HSPs were reported to play a pivotal role in the preservation of the intestinal barrier function (Petrof et al., 2004). Dokladny K et al. suggested that the upregulation of occludin expression mediated by HSPs may be an important mechanism involved in the maintenance of intestinal epithelial tight junction barrier function during heat stress (Dokladny et al., 2006). Using Caco2 colonic epithelial cells it was shown that HSP72 can directly bind and stabilize tight junctionassociated proteins, such as zonula occludens (Musch et al., 1999). Also HSP25 takes part in the stabilization of cell-cell contact, and epithelial cells transfected with antisense to HSP25 demonstrated reduced interleukin-11-mediated cytoprotection, which refer to the protective role of HSPs (Ropeleski et al., 2003). The connection between other HSPs and tight junction proteins was also demonstrated (Tsapara et al., 2006). Furthermore in the pathomechanism leading to villous atrophy the degradation of the extracellular matrix by matrix metalloproteinases may be also implicated. Matrix metalloproteinases belong to a group of zinc-dependent proteins, which are normally produced at very low concentrations and have a primary role in repairing tissue injury and remodelling (Zitka et al., 2010). In the gut of coeliac disease patients the expression of matrix metalloproteinase-1, matrix metalloproteinase-3 and a tissue inhibitor of metalloproteinases were increased, which suggest the importance of these proteases and protease inhibitors in the pathomechanism of coeliac disease (Daum et al., 1999). Furthermore, the elevated levels of tumor necrosis factor alpha during $\mathrm{T}$ cell mediated immune response in the lamina propria, which is also associated with mucosal injury, increased the expression of matrix metalloproteinases promoting mucosal degradation (Pender et al., 1997). A correlation between matrix metalloproteinases and HSPs was also demonstrated by Sims JD et al. Extracellular HSP90a was shown to activate matrix metalloproteinase-2. Cochaperones HSP70 and HSP40 increased the association of HSP90a and matrix metalloproteinase-2 in vitro and enhanced the HSP90a-mediated activation of matrix metalloproteinase-2, leading to increased cell migration (Sims et al., 2011). HSP60 may induce tumor necrosis factor alpha and matrix metalloproteinase production by macrophages (Kol et al., 1998). Based on these results HSPs have an important regulatory role in the maintenance of epithelial barrier functions.

\section{Recent facts and research results: HSPs and coeliac disease}

Recently there are only few data in the literature about the direct connection between HSPs and coeliac disease. Most of our knowledge about the involvement of HSPs in the intestinal tract is based on the results found in other gastrointestinal disorders and gut disease models. Here we summarize the recent research results related to HSPs and coeliac disease based also on findings of our research group. Furthermore we take an outlook to other intestinal abnormalities with specially focus on inflammatory bowel disease because there are similarities between the pathomechanism of inflammatory bowel disease (mainly Crohn's disease) and coeliac disease. 


\subsection{Localization of the HSPs in the gastrointestinal tract}

Studies examining the HSP expression have been shown, that however HSPs are present in all tissues, there are differences in their localization and amount throughout the gastrointestinal tract (Tanguay et al., 1993). Normally high expression of HSPs (such as HSP25 and HSP72) was found in gastric mucosal epithelial cells and in colon epithelial cells. Explanation for this phenomenon may be the fact, that these parts of the gastrointestinal tract are exposed to continuously high acidic $\mathrm{pH}$, mechanical stress or bacterial fermentation, which microenvironment may promote HSP response (Kojima et al., 2003). In contrast, the expression of HSPs in the small intestine is negligible under normal, stress-free circumstances, except the distal part of the ileum, which is exposed to high amounts of enteric bacteria. This luminal microflora and their metabolic products may direct the expression of HSPs in gut epithelial cells (Arvans et al., 2005). Under cellular stress conditions increased expression of HSPs were found also in other parts of the small intestine (Petrof et al., 2004). Generally, HSPs are predominantly localized in the epithelial cells rather than in the underlying lamina propria in the gastrointestinal tract suggesting that HSPs may have crucial role in the protection of epithelial cells preserving their function and structure (Kojima et al., 2003).

\subsection{HSPs in coeliac disease: recent research results}

Since mechanical, chemical or oxidative stress can impair mucosal integrity (Lewis \& McKay, 2009) and has crucial role in the development of coeliac disease, it is important to understand its molecular mechanism. Because HSPs were demonstrated to have mainly cytoprotective function under stress circumstances (Kalmar \& Greensmith, 2009), it is very actual to examine the potential involvement of HSPs in the pathogenesis of coeliac disease. Three genes of the HSP70 family are located in the major histocompatibility complex class III region. These genes are of particularly interest since the HSPs seem to be involved in the antigen processing and presentation (Pierce et al., 1991) and are thought to play a role in the pathogenesis in some autoimmune-like systemic disorders (Panchapakesan et al., 1992). In 1993 Partanen et al. examined 19 families with patients suffering from celiac disease and 95 individuals from the normal population and found that gene frequencies in the affected haplotypes of the heat-shock protein 70 gene cluster significantly deviated from those observed in the normal population. Based on their results they suggested, that polymorphism of human leukocyte antigen-linked HSP70 (called HSP70-2) gene may be involved in the pathomechanism of coeliac disease (Partanen et al., 1993). Ramos-Arroyo et al. studied the polymorphisms in the 5' regulatory region of the HSP70-1 gene and performed genomic human leukocyte antigen-DQ and -DR typing in 128 patients with coeliac disease and 94 healthy controls. They found that among coeliac disease patients the frequency of the C allele of HSP70-1 gene was significantly elevated. Furthermore, those individuals, who expressed the classical human leukocyte antigen alleles in coeliac disease and also carried the HSP70-1 CC genotype, were twelve times more likely to develop coeliac disease than the matched controls. The authors concluded that HSP70-1 gene might be a component of the high risk haplotype, playing a role as an additional predisposing gene for coeliac disease (Ramos-Arroyo et al., 2001). Our research group first examined the expression of HSP72, a member of HSP70 family in the duodenal mucosa of children with coeliac disease (Sziksz et al., 2010). We demonstrated increased mRNA expression and 
protein levels of HSP72 in their duodenal mucosa localized mainly in the villous enterocytes and in the immune cells of the lamina propria. We suggest that HSP72 may have role in the defense against the gliadin-mediated cytotoxicity partly because of its antiapoptotic effects fostering the survival of epithelial cells. Furthermore, earlier we also demonstrated increased Toll-like receptor 2 and Toll-like receptor 4 expressions in the duodenal mucosa of patients with coeliac disease localized in the villous enterocytes and immune cells of the lamina propria (Szebeni et al., 2007) similarly to the tissue distribution of HSP72. Cario et al. showed, that activation of Toll-like receptor 2 can preserve tight junction proteins (such as zonula occludens 1) associated intestinal barrier integrity against stress-induced damage through the promotion of phosphatidylinositol 3-kinase/Akt-mediated signaling pathway (Cario et al., 2007). Since HSPs can serve as ligands of Toll-like receptors (Asea, 2008), our data suggest that HSP72-Toll-like receptor 2/Toll-like receptor 4 signaling may modify the immune response against gluten peptides and may alter the integrity of intestinal barrier. We also analyzed the HSP72 expression in coeliac disease patients maintained on gluten free diet and found markedly decreased levels of HSP72 in their duodenal mucosa compared to untreated children with coeliac disease, but its level remained higher than that in controls. We propose, that HSP72 as a "danger signal" for the immune cells may promote their protection against damage in coeliac disease. Since intact protein absorption is thought to be a causative factor in celiac disease, Yang et al. examined transepithelial electric resistance and permeability after performing heat stress in vitro using T84 human intestinal epithelial cells. Heat stress significantly increased protein transport across the intestinal epithelial monolayer and this heat stress-induced T84 monolayer barrier disruption was inhibited by pretreatment with HSP70 suggesting the intestinal barrier protective role of HSP70 (Yang et al., 2007). Examining the involvement of other HSPs in coeliac disease, Iltanen et al. analyzed jejunal biopsies of seventy-eight children with clinical suspicion of coeliac disease. They found increased expression of mitochondrial HSP65 in the epithelial cells in $80 \%$ of patients suffering from coeliac disease, but in only $7 \%$ of control individuals. Moreover, enhanced HSP65 levels were associated with higher gammadelta+ $\mathrm{T}$ cell densities and serum Immunglobulin A-class endomysial autoantibodies. They concluded that enhanced expression of epithelial cell stress proteins might be indicators also in some patients, which were excluded for the disease on biopsy (Iltanen et al., 1999). Yeboah et al. investigated the involvement of alphaB-crystallin, a small HSP in the pathomechanism of coeliac disease. Biopsy specimens of 12 celiac patients and 10 control individuals were investigated by immunoperoxidase screening. The intestinal epithelial cells of patients with coeliac disease stained more intensively for the sHSP alphaB-crystallin than that of controls. The amount and intracellular distribution of alphaB-crystallin in the duodenal mucosa of the patients with coeliac disease were closely related to the degree of villous atrophy, which may indicate its involvement in mucosal damage (Yeboah \& White, 2001). In summary, these data suggest that HSPs may be involved in the pathomechanism of coeliac disease, but further studies are needed to clarify their more precise role.

\subsection{HSPs in other gastrointestinal disorders}

Since stress-induced tissue damage is involved in different gastrointestinal diseases, HSPs were examined also in gastric ulcer (Rokutan, 2000), chronic pancreatitis (Ogata et al., 2000) and inflammatory bowel disease, that means Crohn's disease and ulcerative colitis (Rodolico et al., 2010). Similarly to coeliac disease, inflammatory bowel disease is an 
inflammatory disease of the intestinal tract and there are relevant overlaps in their pathology. In both diseases the inflammation leads to the damage of the intestinal mucosa resulting in enhanced permeability and impaired function of the epithelial barrier in genetically susceptible individuals (Festen et al., 2009). Increased HSP70 (Ludwig et al., 1999), HSP60 and HSP10 (Rodolico et al., 2010) expression was observed in the colon mucosa of patients with inflammatory bowel disease. HSPs localized mainly within the epithelial cells and in lesser extent in the lamina propria (Rodolico et al., 2010). Protective functions of HSPs were demonstrated in inflammatory gastrointestinal diseases (Otaka et al., 2010). Using heat shock factor 1-null mice and HSP70 overexpressing transgenic mice HSP70 seems to have a protective role against colitis: various mechanisms may be involved in this process, such as the suppression of proinflammatory cytokines and cell adhesion molecules expression or the inhibition of programmed cell death (Tanaka \& Mizushima, 2009). A correlation between HSPs and probiotics was reported. Advantageous effect of probiotics was demonstrated in inflammatory bowel disease (Sartor, 2004) and one mechanism responsible for this can be the ability, that probiotics may induce the expression of HSPs (Dotan \& Rachmilewitz, 2005). Tao et al. found that treatment of intestinal epithelial cells with the probiotic Lactobacillus GG strain induces HSP72 expression, which contributes to the beneficial clinical effects through preservation of cytoskeletal integrity (Tao et al., 2006). Using Caco-2 colonic epithelial cells Musch et al. demonstrated that HSP72 can bind and stabilize key cytoskeleton-associated proteins, such as alpha-actinin, or tight junction-associated proteins, such as zonula occludens 1 (Musch et al., 1999). In summary, cytoprotective effects of HSPs were suggested in different gastrointestinal diseases.

\section{Future directions}

Based on these beneficial effects of HSPs they can be potential therapeutic targets in the future. Using transgenic mice Mizushima et al. reported that a non-toxic HSP-inducer called geranylgeranylacetone, which is basically an anti-ulcer drug, achieves its anti-ulcer effect through induction of HSPs, which are protective against irritant-induced gastric lesions (Mizushima, 2010). Furthermore they reported that geranylgeranylacetone has protective effects against inflammatory bowel disease-related colitis and prevents lesions of the small intestine by the induction of HSPs. These findings predict the possibility, that HSPs may have therapeutic potential also in coeliac disease. Recently there are investigations to find HSP based therapies in other disorders, for instance the development of HSP-based vaccines to treat cancer with promising opportunities, because tumor derived HSP-peptide complexes are able to induce immunity against several malignancies as shown in preclinical studies (di Pietro et al., 2009). In conclusion, in the future it will be important to understand the precise role of HSPs in the pathomechanism of coeliac disease, because due to their protective effects HSPs could be regarded as potential therapeutic agents to treat several gastrointestinal diseases, maybe also coeliac disease.

\section{Acknowledgments}

Ádam Vannay and Gábor Veres are holders of the János Bolyai Research grant; this book chapter was supported by the János Bolyai Research Scholarschip of the Hungarian Academy of Sciences and by OTKA-K81117, -84087/2010, -T-71730 grants. 


\section{References}

Akerfelt, M.; Morimoto, RI. \& Sistonen L. (2010). Heat shock factors: integrators of cell stress, development and lifespan. Nat Rev Mol Cell Biol. 11(8):545-55.

Akerfelt, M.; Trouillet, D.; Mezger, V.\& Sistonen, L. (2007). Heat shock factors at a crossroad between stress and development. Ann N Y Acad Sci. 1113:15-27.

Al Refaii, A. \& Alix, JH. (2009). Ribosome biogenesis is temperature-dependent and delayed in Escherichia coli lacking the chaperones DnaK or DnaJ. Mol Microbiol. 71(3):74862.

Alaedini, A. \& Green, PH. (2008). Autoantibodies in celiac disease. Autoimmunity. 41(1):1926.

Alaedini, A. \& Green, PH. (2005). Narrative review: celiac disease: understanding a complex autoimmune disorder. Ann Intern Med. 142(4):289-98.

Anckar, J. \& Sistonen, L. (2007). Heat shock factor 1 as a coordinator of stress and developmental pathways. Adv Exp Med Biol. 594:78-88.

Arrigo, AP., Simon, S., Gibert, B., Kretz-Remy, C., Nivon, M., Czekalla, A., Guillet, D., Moulin, M., Diaz-Latoud, C. \& Vicart, P. (2007). Hsp27 (HspB1) and alphaBcrystallin (HspB5) as therapeutic targets. FEBS Lett. 581(19):3665-74.

Arrigo, AP (2007). The cellular "networking" of mammalian Hsp27 and its functions in the control of protein folding, redox state and apoptosis. Adv Exp Med Biol. 594:14-26.

Arvans, DL., Vavricka, SR., Ren, H., Musch, MW., Kang, L., Rocha, FG., Lucioni, A., Turner, JR., Alverdy, J. \& Chang, EB. (2005). Luminal bacterial flora determines physiological expression of intestinal epithelial cytoprotective heat shock proteins 25 and 72. Am J Physiol Gastrointest Liver Physiol. 288(4):G696-704.

Asano, T., Tanaka, K., Yamakawa, N., Adachi, H., Sobue, G., Goto, H., Takeuchi, K. \& Mizushima, T.(2009). HSP70 confers protection against indomethacin-induced lesions of the small intestine. J Pharmacol Exp Ther. 330(2):458-67.

Asea, A., Kraeft, SK., Kurt-Jones, EA., Stevenson, MA., Chen, LB., Finberg, RW., Koo, GC. \& Calderwood, SK. (2000). HSP70 stimulates cytokine production through a coeliac disease14-dependant pathway, demonstrating its dual role as a chaperone and cytokine. Nat Med. 6(4):435-42.

Asea, A. (2008). Heat shock proteins and toll-like receptors. Handb Exp Pharmacol. (183):11127.

Aufricht, C. (2004). HSP: helper, suppressor, protector. Kidney Int. 65(2):739-40.

Avery, SV. (2011) . Molecular targets of oxidative stress. Biochem J. 434(2):201-10.

Aztatzi-Santillán E, Nares-López FE, Márquez-Valadez B, Aguilera P, Chánez-Cárdenas ME. The protective role of heme oxygenase- 1 in cerebral ischemia. Cent Nerv Syst Agents Med Chem. 2010 Dec 1;10(4):310-6.

Baldassarre, M., Laneve, AM., Grosso, R. \& Laforgia, N. (2008). Celiac disease: pathogenesis and novel therapeutic strategies. Endocr Metab Immune Disord Drug Targets. $8(3): 152-8$.

Baniwal, SK., Bharti, K., Chan, KY., Fauth, M., Ganguli, A., Kotak, S., Mishra, SK., Nover, L., Port, M., Scharf, KD., Tripp, J., Weber, C., Zielinski, D., \& von Koskull-Döring, P. (2004). Heat stress response in plants: a complex game with chaperones and more than twenty heat stress transcription factors. J Biosci. 29(4):471-87.

Barends, TR., Werbeck, ND. \& Reinstein, J. (2010). Disaggregases in 4 dimensions. Curr Opin Struct Biol. 20(1):46-53. 
Bellmann, K., Burkart, V., Bruckhoff, J., Kolb, H. \& Landry, J. (2000) p38-dependent enhancement of cytokine-induced nitric-oxide synthase gene expression by heat shock protein 70. J Biol Chem. 275(24):18172-9.

Bhatia, V. \& Tandon, RK. (2005). Stress and the gastrointestinal tract. J Gastroenterol Hepatol. 20(3):332-9.

Biamonti, G. \& Caceres, JF. (2009). Cellular stress and RNA splicing. Trends Biochem Sci. 34(3):146-53.

Binder, RJ., Vatner, R. \& Srivastava P. (2004). The heat-shock protein receptors: some answers and more questions. Tissue Antigens. 64(4):442-51.

Borkovich, KA., Farrelly, FW., Finkelstein, DB., Taulien, J. \& Lindquist, S. (1989) Hsp82 is an essential protein that is required in higher concentrations for growth of cells at higher temperatures. Mol Cell Biol. 9(9):3919-30.

Briani, C., Samaroo, D. \& Alaedini, A. (2008). Celiac disease: from gluten to autoimmunity. Autoimmun Rev. 7(8):644-50.

Bruewer, M., Samarin, S. \& Nusrat A. (2006). Inflammatory bowel disease and the apical junctional complex. Ann N Y Acad Sci. 1072:242-52.

Bukau, B., Weissman, J. \& Horwich, A. (2006). Molecular chaperones and protein quality control. Cell. 125(3):443-51.

Burel, C., Mezger, V., Pinto, M., Rallu, M., Trigon, S. \& Morange, M. (1992). Mammalian heat shock protein families. Expression and functions. Experientia. 48(7):629-34.

Caccamo, D., Currò, M. \& Ientile, R. (2010). Potential of transglutaminase 2 as a therapeutic target. Expert Opin Ther Targets. 14(9):989-1003.

Cario, E., Gerken, G. \& Podolsky, DK. (2007). Toll-like receptor 2 controls mucosal inflammation by regulating epithelial barrier function. Gastroenterology. 132(4):135974.

Carper, SW., Duffy, JJ. \& Gerner, EW. (1987). Heat shock proteins in thermotolerance and other cellular processes. Cancer Res. 47(20):5249-55.

Chen, SL., Yang, CT., Yang, ZL., Guo, RX., Meng, JL., Cui, Y., Lan, AP., Chen, PX. \& Feng, JQ. (2010). Hydrogen sulphide protects H9c2 cells against chemical hypoxiainduced injury. Clin Exp Pharmacol Physiol. 37(3):316-21.

Chhabra, A., Verma, A. \& Mehta, K. (2009). Tissue transglutaminase promotes or suppresses tumors depending on cell context. Anticancer Res. 29(6):1909-19.

Choi, K., Ni, L. \& Jonakait, GM. (2011). Fas ligation and tumor necrosis factor a activation of murine astrocytes promote heat shock factor- 1 activation and heat shock protein expression leading to chemokine induction and cell survival. J Neurochem. 116(3):438-48.

Ciccocioppo, R., Di Sabatino, A., Parroni, R., Muzi, P., D'Alò, S., Ventura, T., Pistoia, MA., Cifone, MG. \& Corazza, GR. (2001). Increased enterocyte apoptosis and Fas-Fas ligand system in celiac disease. Am J Clin Pathol. 115(4):494-503.

Ciocca, DR. \& Calderwood SK. (2005). Heat shock proteins in cancer: diagnostic, prognostic, predictive, and treatment implications. Cell Stress Chaperones. 10(2):86-103.

Creagh, EM., Carmody, RJ. \& Cotter, TG. (2000). Heat shock protein 70 inhibits caspasedependent and -independent apoptosis in Jurkat T cells. Exp Cell Res. 257(1):58-66.

Csermely, P., Söti, C. \& Blatch GL. (2007). Chaperones as parts of cellular networks. Adv Exp Med Biol. 594:55-63. 
Dantuma, NP. \& Lindsten, K. (2010). Stressing the ubiquitin-proteasome system. Cardiovasc Res. 85(2):263-71.

Daugaard, M., Kirkegaard-Sørensen, T., Ostenfeld, MS., Aaboe, M., Høyer-Hansen, M., Orntoft, TF., Rohde, M. \& Jäättelä M. (2007). Lens epithelium-derived growth factor is an Hsp70-2 regulated guardian of lysosomal stability in human cancer. Cancer Res. 67(6):2559-67.

Daum, S., Bauer, U., Foss, HD., Schuppan, D., Stein, H., Riecken, EO. \& Ullrich, R. (1999). Increased expression of mRNA for matrix metalloproteinases-1 and -3 and tissue inhibitor of metalloproteinases-1 in intestinal biopsy specimens from patients with coeliac disease. Gut. 44(1):17-25.

di Pietro, A., Tosti, G., Ferrucci, PF. \& Testori A. (2009). Heat shock protein peptide complex 96-based vaccines in melanoma: How far we are, how far we can get. Hum Vaccin. $5(11)$.

Di Sabatino, A., Ciccocioppo, R., D'Alò, S., Parroni, R., Millimaggi, D., Cifone, MG. \& Corazza, GR. (2001). Intraepithelial and lamina propria lymphocytes show distinct patterns of apoptosis whereas both populations are active in Fas based cytotoxicity in coeliac disease. Gut. 49(3):380-6.

Di Sabatino, A., Pickard, KM., Gordon, JN., Salvati, V., Mazzarella, G., Beattie, RM., Vossenkaemper, A., Rovedatti, L., Leakey, NA., Croft, NM., Troncone, R., Corazza, GR., Stagg, AJ., Monteleone, G. \& MacDonald, TT. (2007). Evidence for the role of interferon-alfa production by dendritic cells in the Th1 response in celiac disease. Gastroenterology. 133(4):1175-87.

DiDomenico, BJ., Bugaisky, GE. \& Lindquist S. (1982). Heat shock and recovery are mediated by different translational mechanisms. Proc Natl Acad Sci U $S$ A. 79(20):6181-5.

Diosdado, B., van Oort, E. \& Wijmenga, C. (2005). "Coelionomics": towards understanding the molecular pathology of coeliac disease. Clin Chem Lab Med. 43(7):685-95.

Doganci, T. \& Bozkurt, S. (2004). Celiac disease with various presentations. Pediatr Int. 46(6):693-6.

Dokladny, K., Moseley, PL. \& Ma, TY. (2006). Physiologically relevant increase in temperature causes an increase in intestinal epithelial tight junction permeability. Am J Physiol Gastrointest Liver Physiol. 290(2):G204-12.

Dollins, DE., Warren, JJ., Immormino, RM. \& Gewirth, DT. (2007). Structures of GRP94nucleotide complexes reveal mechanistic differences between the hsp90 chaperones. Mol Cell. 28(1):41-56.

Dotan, I. \& Rachmilewitz D. (2005). Probiotics in inflammatory bowel disease: possible mechanisms of action. Curr Opin Gastroenterol. 21(4):426-30.

Dudeja, V., Mujumdar, N., Phillips, P., Chugh, R., Borja-Cacho, D., Dawra, RK., Vickers, SM. \& Saluja AK. (2009). Heat shock protein 70 inhibits apoptosis in cancer cells through simultaneous and independent mechanisms. Gastroenterology. 136(5):177282.

Dudeja, V., Vickers, SM. \& Saluja AK. (2009). The role of heat shock proteins in gastrointestinal diseases.Gut. 58(7):1000-9.

Ehrenschwender, M. \& Wajant, H. (2009). The role of FasL and Fas in health and disease. Adv Exp Med Biol. 647:64-93. 
Elli, L., Bergamini, CM., Bardella, MT. \& Schuppan, D. (2009). Transglutaminases in inflammation and fibrosis of the gastrointestinal tract and the liver. Dig Liver Dis. 41(8):541-50.

Ellis, RJ., van der Vies, SM., \& Hemmingsen, SM. (1989). The molecular chaperone concept. Biochem Soc Symp. 55:145-53.

Evans, CG., Chang, L. \& Gestwicki, JE. (2010). Heat shock protein 70 (hsp70) as an emerging drug target. J Med Chem. 53(12):4585-602.

Farhadi, A., Banan, A., Fields, J. \& Keshavarzian, A. (2003). Intestinal barrier: an interface between health and disease. J Gastroenterol Hepatol. 18(5):479-97.

Festen, EA., Szperl, AM., Weersma, RK., Wijmenga, C. \& Wapenaar, MC. (2009). Inflammatory bowel disease and celiac disease: overlaps in the pathology and genetics, and their potential drug targets. Endocr Metab Immune Disord Drug Targets. 9(2):199-218.

Fleckenstein, B., Qiao, SW., Larsen, MR., Jung, G., Roepstorff, P. \& Sollid, LM. (2004). Molecular characterization of covalent complexes between tissue transglutaminase and gliadin peptides. J Biol Chem. 279(17):17607-16.

Flohé, SB., Brüggemann, J., Lendemans, S., Nikulina, M., Meierhoff, G., Flohé, S. \& Kolb H. (2003). Human heat shock protein 60 induces maturation of dendritic cells versus a Th1-promoting phenotype. J Immunol. 170(5):2340-8

Fric, P., Gabrovska, D. \& Nevoral, J. (2011). Celiac disease, gluten-free diet, and oats. Nutr Rev. 69(2):107-15.

Fujimoto, M. \& Nakai, A. (2010). The heat shock factor family and adaptation to proteotoxic stress. FEBS J. 277(20):4112-25.

Gabai, VL., Yaglom, JA., Volloch, V., Meriin, AB., Force, T., Koutroumanis, M., Massie, B., Mosser, DD., Sherman, MY. (2000). Hsp72-mediated suppression of c-Jun Nterminal kinase is implicated in development of tolerance to caspase-independent cell death. Mol Cell Biol. 20(18):6826-36.

Geiger, PC. \& Gupte, AA. (2011). Heat shock proteins are important mediators of skeletal muscle insulin sensitivity. Exerc Sport Sci Rev. 39(1):34-42

Ghayour-Mobarhan, M., Rahsepar, AA., Tavallaie, S., Rahsepar, S. \& Ferns GA. (2009). The potential role of heat shock proteins in cardiovascular disease: evidence from in vitro and in vivo studies. Adv Clin Chem. 48:27-72.

Ghosh, JC., Siegelin, MD., Dohi, T. \& Altieri, DC. (2010). Heat shock protein 60 regulation of the mitochondrial permeability transition pore in tumor cells. Cancer Res. 70(22):8988-93.

Gianfrani, C., Auricchio, S. \& Troncone, R. (2005). Adaptive and innate immune responses in celiac disease. Immunol Lett. 99(2):141-5.

Giovannini, C., Matarrese, P., Scazzocchio, B., Varí, R., D'Archivio, M., Straface, E., Masella, R., Malorni, W. \& De Vincenzi M. (2003). Wheat gliadin induces apoptosis of intestinal cells via an autocrine mechanism involving Fas-Fas ligand pathway. FEBS Lett. 540(1-3):117-24.

Glickman, MH. \& Ciechanover, A. (2002). The ubiquitin-proteasome proteolytic pathway: destruction for the sake of construction. Physiol Rev. 82(2):373-428.

Graf, PC. \& Jakob, U. (2002). Redox-regulated molecular chaperones. Cell Mol Life Sci. 59(10):1624-31. 
Green, PH. (2005). The many faces of celiac disease: clinical presentation of celiac disease in the adult population. Gastroenterology. 128(4 Suppl 1):S74-8.

Gué, M., Bonbonne, C., Fioramonti, J., Moré, J., Del Rio-Lachèze, C., Coméra, C. \& Buéno, L. (1997). Stress-induced enhancement of colitis in rats: CRF and arginine vasopressin are not involved. Am J Physiol. 272(1 Pt 1):G84-91.

Gupta, V. \& Kohli A. (2010). Celiac disease associated with recurrent Guillain Barre syndrome. Indian Pediatr. 47(9):797-8.

Gyrd-Hansen, M., Nylandsted, J. \& Jäättelä, M. (2004). Heat shock protein 70 promotes cancer cell viability by safeguarding lysosomal integrity. Cell Cycle. 3(12):1484-5.

Hao, H., Naomoto, Y., Bao, X., Watanabe, N., Sakurama, K., Noma, K., Motoki, T., Tomono, Y., Fukazawa, T., Shirakawa, Y., Yamatsuji, T., Matsuoka, J. \& Takaoka M. (2010). HSP90 and its inhibitors. Oncol Rep. 23(6):1483-92.

Haslbeck, M., Franzmann, T., Weinfurtner, D. \& Buchner J. (2005). Some like it hot: the structure and function of small heat-shock proteins. Nat Struct Mol Biol. 2005 Oct;12(10):842-6.

Hauet-Broere, F., Wieten, L., Guichelaar, T., Berlo, S., van der Zee, R. \& Van Eden W. (2006). Heat shock proteins induce T cell regulation of chronic inflammation. Ann Rheum Dis. 65 Suppl 3:iii65-8

Heo, JM. \& Rutter, J. (2011). Ubiquitin-dependent mitochondrial protein degradation. (2011). Int J Biochem Cell Biol. 2011 Jun 12. Epub ahead of print.

Holmberg, CI., Hietakangas, V., Mikhailov, A., Rantanen, JO., Kallio, M., Meinander, A., Hellman, J., Morrice, N., MacKintosh, C., Morimoto, RI., Eriksson, JE. \& Sistonen, L. (2001). Phosphorylation of serine 230 promotes inducible transcriptional activity of heat shock factor 1. EMBO J. 20(14):3800-10.

Horwitz, J. (1992). Alpha-crystallin can function as a molecular chaperone. Proc Natl Acad Sci U S A. 89(21):10449-53.

Hüe, S., Mention, JJ., Monteiro, RC., Zhang, S., Cellier, C., Schmitz, J., Verkarre, V., Fodil, N., Bahram, S., Cerf-Bensussan, N. \& Caillat-Zucman, S. (2004). A direct role for NKG2D/MICA interaction in villous atrophy during celiac disease. Immunity. 21(3):367-77.

Ilangovan, G., Osinbowale, S., Bratasz, A., Bonar, M., Cardounel, AJ., Zweier, JL. \& Kuppusamy, P. (2004). Heat shock regulates the respiration of cardiac H9c2 cells through upregulation of nitric oxide synthase. Am J Physiol Cell Physiol. 287(5):C1472-8

Iltanen, S., Rantala, I., Laippala, P., Holm, K., Partanen, J. \& Maki, M. (1999). Expression of HSP-65 in jejunal epithelial cells in patients clinically suspected of coeliac disease. Autoimmunity. 31(2):125-32.

Ivanov, AI., Nusrat, A. \& Parkos, CA. (2004). The epithelium in inflammatory bowel disease: potential role of endocytosis of junctional proteins in barrier disruption. Novartis Found Symp. 263:115-24; discussion 124-32, 211-8.

Jabri, B., Kasarda, DD. \& Green, PH. (2005). Innate and adaptive immunity: the yin and yang of celiac disease. Immunol Rev. 206:219-31.

Jabri, B. \& Sollid, LM. (2006). Mechanisms of disease: immunopathogenesis of celiac disease. Nat Clin Pract Gastroenterol Hepatol. 3(9):516-25.

Jantschitsch, C. \& Trautinger, F. (2003). Heat shock and UV-B-induced DNA damage and mutagenesis in skin. Photochem Photobiol Sci. 2(9):899-903. 
John, LJ., Fromm, M., \& Schulzke, JD. (2011). Epithelial Barriers in Intestinal Inflammation. Antioxid Redox Signal. 15(5):1255-70.

Johnson, JD. \& Fleshner, M. (2006). Releasing signals, secretory pathways, and immune function of endogenous extracellular heat shock protein 72. J Leukoc Biol. 79(3):42534.

Kalmar, B. \& Greensmith, L. (2009). Induction of heat shock proteins for protection against oxidative stress. Adv Drug Deliv Rev. 61(4):310-8.

Kaukinen, K., Lindfors, K., Collin, P., Koskinen, O. \& Mäki, M. (2010). Coeliac disease--a diagnostic and therapeutic challenge. Clin Chem Lab Med. 48(9):1205-16.

Kelley, PM. \& Schlesinger, MJ. (1978). The effect of amino acid analogues and heat shock on gene expression in chicken embryo fibroblasts. Cell. 15(4):1277-86.

Kelly, KJ. (2005). Heat shock (stress response) proteins and renal ischemia/reperfusion injury. Contrib Nephrol. 148:86-106.

Kiang, JG. (2004). Inducible heat shock protein $70 \mathrm{kD}$ and inducible nitric oxide synthase in hemorrhage/resuscitation-induced injury. Cell Res. 14(6):450-9.

Kim, S. \& Coulombe, PA. (2007). Intermediate filament scaffolds fulfill mechanical, organizational, and signaling functions in the cytoplasm. Genes Dev. 21(13):1581-97.

Kim, SH., Hur, WY., Kang, CD., Lim, YS., Kim, DW. \& Chung, BS. (1997). Involvement of heat shock factor in regulating transcriptional activation of MDR1 gene in multidrug-resistant cells. Cancer Lett. 115(1):9-14.

Kojima, K., Musch, MW., Ren, H., Boone, DL., Hendrickson, BA., Ma, A. \& Chang, EB. (2003). Enteric flora and lymphocyte-derived cytokines determine expression of heat shock proteins in mouse colonic epithelial cells. Gastroenterology. 124(5):1395407.

Kol, A., Sukhova, GK., Lichtman, AH. \& Libby, P. (1998). Chlamydial heat shock protein 60 localizes in human atheroma and regulates macrophage tumor necrosis factoralpha and matrix metalloproteinase expression. Circulation. 98(4):300-7.

Kriehuber, T., Rattei, T., Weinmaier, T., Bepperling, A., Haslbeck, M. \& Buchner, J. (2010). Independent evolution of the core domain and its flanking sequences in small heat shock proteins. FASEB J. 24(10):3633-42.

Kuwabara, T., Otaka, M., Itoh, H., Zeniya, A., Fujimori, S., Otani, S., Tashima, Y. \& Masamune, O. (1994). Regulation of $60-\mathrm{kDa}$ heat shock protein expression by systemic stress and 5-hydroxytryptamine in rat colonic mucosa. J Gastroenterol. 29(6):721-6.

Large, AT., Goldberg, MD. \& Lund, PA. (2009). Chaperones and protein folding in the archaea. Biochem Soc Trans. 37(Pt 1):46-51.

Laufen, T., Mayer, MP., Beisel, C., Klostermeier, D., Mogk, A., Reinstein, J. \& Bukau, B. (1999). Mechanism of regulation of hsp70 chaperones by DnaJ cochaperones. Proc Natl Acad Sci U S A. 96(10):5452-7.

Lemaux, PG., Herendeen, SL., Bloch, PL. \& Neidhardt, FC. (1978). Transient rates of synthesis of individual polypeptides in E. coli following temperature shifts. Cell. 13(3):427-34.

Levenstein, S., Prantera, C., Varvo, V., Scribano, ML., Andreoli, A., Luzi, C., Arcà, M., Berto, E., Milite, G. \& Marcheggiano, A. (2000). Stress and exacerbation in ulcerative colitis: a prospective study of patients enrolled in remission. Am J Gastroenterol. 95(5):1213-20. 
Levitsky, DI., Pivovarova, AV., Mikhailova, VV. \& Nikolaeva OP. (2008). Thermal unfolding and aggregation of actin. FEBS J. 275(17):4280-95.

Lewis, K. \& McKay, DM. (2009). Metabolic stress evokes decreases in epithelial barrier function. Ann N Y Acad Sci. 1165:327-37.

Li, P., Nijhawan, D., Budihardjo, I., Srinivasula, SM., Ahmad, M., Alnemri, ES \& Wang, X. (1997). Cytochrome $\mathrm{c}$ and dATP-dependent formation of Apaf-1/caspase-9 complex initiates an apoptotic protease cascade. Cell. 91(4):479-89.

Li, Z., Menoret, A. \& Srivastava, P. (2002). Roles of heat-shock proteins in antigen presentation and cross-presentation. Curr Opin Immunol. 14(1):45-51.

Liang, P. \& MacRae, TH. (1997). Molecular chaperones and the cytoskeleton. J Cell Sci. 110 ( Pt 13):1431-40.

Limón-Pacheco, J. \& Gonsebatt, ME. (2009). The role of antioxidants and antioxidant-related enzymes in protective responses to environmentally induced oxidative stress. Mutat Res. 674(1-2):137-47.

Liu, X., Xu, L., Liu, Y., Tong, X., Zhu, G., Zhang, XC., Li, X. \& Rao, Z. (2009). Crystal structure of the hexamer of human heat shock factor binding protein 1. Proteins. 75(1):1-11.

Ludwig, D., Stahl, M., Ibrahim, ET., Wenzel, BE., Drabicki, D., Wecke, A., Fellermann, K. \& Stange, EF. (1999). Enhanced intestinal expression of heat shock protein 70 in patients with inflammatory bowel diseases. Dig Dis Sci. 44(7):1440-7.

Lyte, M., Vulchanova, L. \& Brown, DR. (2011). Stress at the intestinal surface: catecholamines and mucosa-bacteria interactions. Cell Tissue Res. 343(1):23-32.

Malmendal, A., Overgaard, J., Bundy, JG., Sørensen, JG., Nielsen, NC., Loeschcke, V., Holmstrup, M. (2006). Metabolomic profiling of heat stress: hardening and recovery of homeostasis in Drosophila. Am J Physiol Regul Integr Comp Physiol. 291(1):R205-12.

Malorni, W., Farrace, MG., Rodolfo, C. \& Piacentini, M. (2008). Type 2 transglutaminase in neurodegenerative diseases: the mitochondrial connection. Curr Pharm Des. 14(3):278-88.

Maniar, VP., Yadav, SS. \& Gokhale, YA. (2010). Intractable seizures and metabolic bone disease secondary to celiac disease. J Assoc Physicians India. 58:512-5.

Maupin-Furlow, JA., Wilson, HL., Kaczowka, SJ. \& Ou, MS. (2000). Proteasomes in the archaea: from structure to function. Front Biosci. 5:D837-65.

Maurizi, MR \& Xia, D. (2004). Protein binding and disruption by Clp/Hsp100 chaperones. Structure. 12(2):175-83.

Mayer, MP. (2010). Gymnastics of molecular chaperones. Mol Cell. 39(3):321-31.

Medzhitov, R. (2001). Toll-like receptors and innate immunity. Nat Rev Immunol. 1(2):135-45.

Miot, M., Reidy, M., Doyle, SM., Hoskins, JR., Johnston, DM., Genest, O., Vitery, MC., Masison, DC. \& Wickner S. (2011). Species-specific collaboration of heat shock proteins (Hsp) 70 and 100 in thermotolerance and protein disaggregation. Proc Natl Acad Sci U S A. 108(17):6915-20.

Mishra, A., Godavarthi, SK., Maheshwari, M., Goswami, A. \& Jana, NR. (2009). The ubiquitin ligase E6-AP is induced and recruited to aggresomes in response to proteasome inhibition and may be involved in the ubiquitination of Hsp70-bound misfolded proteins. J Biol Chem. 284(16):10537-45. 
Mizushima, T. (2010). HSP-dependent protection against gastrointestinal diseases. Curr Pharm Des. 16(10):1190-6.

Moran, L., Mirault, ME., Arrigo, AP., Goldschmidt-Clermont, M. \& Tissières A. (1978). Heat shock of Drosophila melanogaster induces the synthesis of new messenger RNAs and proteins. Philos Trans R Soc Lond B Biol Sci. 283(997):391-406.

Morandi, A., Los, B., Osofsky, L., Autilio-Gambetti, L. \& Gambetti, P. (1989). Ubiquitin and heat shock proteins in cultured nervous tissue after different stress conditions. Prog Clin Biol Res. 317:819-27.

Multhoff, G. (2009). Activation of natural killer cells by heat shock protein 70 . Int J Hyperthermia. 25(3):169-75.

Murray, IA., Daniels, I., Coupland, K., Smith, JA. \& Long RG. (2002). Increased activity and expression of initric oxides in human duodenal enterocytes from patients with celiac disease. Am J Physiol Gastrointest Liver Physiol. 283(2):G319-26.

Musch, MW., Sugi, K., Straus, D. \& Chang, EB. (1999). Heat-shock protein 72 protects against oxidant-induced injury of barrier function of human colonic epithelial Caco2/bbe cells. Gastroenterology. 117(1):115-22.

Noble, EG., Milne, KJ. \& Melling, CW. (2008). Heat shock proteins and exercise: a primer. Appl Physiol Nutr Metab. 33(5):1050-65.

Obermann, WM., Sondermann, H., Russo, AA., Pavletich, NP. \& Hartl, FU. (1998). In vivo function of Hsp90 is dependent on ATP binding and ATP hydrolysis. J Cell Biol. 143(4):901-10.

Odashima, M., Otaka, M., Jin, M., Konishi, N., Sato, T., Kato, S., Matsuhashi, T., Nakamura, C., Watanabe, S. (2002). Induction of a 72-kDa heat-shock protein in cultured rat gastric mucosal cells and rat gastric mucosa by zinc L-carnosine. Dig Dis Sci. 47(12):2799-804.

Odashima, M., Otaka, M., Jin, M., Wada, I., Horikawa, Y., Matsuhashi, T., Ohba, R., Hatakeyama, N., Oyake, J. \& Watanabe, S. (2006). Zinc L-carnosine protects colonic mucosal injury through induction of heat shock protein 72 and suppression of NFkappaB activation. Life Sci. 79(24):2245-50.

Odetti, P., Valentini, S., Aragno, I., Garibaldi, S., Pronzato, MA., Rolandi, E. \& Barreca, T. (1998). Oxidative stress in subjects affected by celiac disease. Free Radic Res. 29(1):17-24.

Ogata, M., Naito, Z., Tanaka, S., Moriyama, Y. \& Asano, G. (2000). Overexpression and localization of heat shock proteins mRNA in pancreatic carcinoma. J Nippon Med Sch.. 67(3):177-85.

Omar, R. \& Pappolla, M. (1993). Oxygen free radicals as inducers of heat shock protein synthesis in cultured human neuroblastoma cells: relevance to neurodegenerative disease. Eur Arch Psychiatry Clin Neurosci. 242(5):262-7.

Osterloh, A. \& Breloer, M. (2008). Heat shock proteins: linking danger and pathogen recognition. Med Microbiol Immunol. 197(1):1-8.

Otaka, M., Odashima, M. \& Watanabe, S. (2006). Role of heat shock proteins (molecular chaperones) in intestinal mucosal protection. Biochem Biophys Res Commun. 348(1):15.

Padmini, E., Lavanya, S. (2011). HSP70-mediated control of endothelial cell apoptosis during pre-eclampsia. Eur J Obstet Gynecol Reprod Biol. 56(2):158-64. 
Panchapakesan J, Daglis M, Gatenby P. Antibodies to $65 \mathrm{kDa}$ and $70 \mathrm{kDa}$ heat shock proteins in rheumatoid arthritis and systemic lupus erythematosus. Immunol Cell Biol. 1992 Oct;70 ( Pt 5):295-300.

Papp, E., Nardai, G., Söti, C. \& Csermely P. (2003). Molecular chaperones, stress proteins and redox homeostasis. Biofactors. 17(1-4):249-57.

Park, HS., Lee, JS., Huh, SH., Seo, JS. \& Choi, EJ. (2001). Hsp72 functions as a natural inhibitory protein of c-Jun N-terminal kinase. EMBO J. 20(3):446-56.

Parsell, DA. \& Lindquist, S. (1993). The function of heat-shock proteins in stress tolerance: degradation and reactivation of damaged proteins. Annu Rev Genet. 27:437-96.

Partanen, J., Milner, C., Campbell, RD., Mäki, M., Lipsanen, V. \& Koskimies, S. (1993). human leukocyte antigen-linked heat-shock protein 70 (HSP70-2) gene polymorphism and celiac disease. Tissue Antigens. 41(1):15-9.

Pearl, LH. \& Prodromou, C. (2006). Structure and mechanism of the Hsp90 molecular chaperone machinery. Annu Rev Biochem. 75:271-94.

Pechan, PM. (1991). Heat shock proteins and cell proliferation. FEBS Lett. 280(1):1-4.

Pekny, M., Lane, EB. (2007). Intermediate filaments and stress. Exp Cell Res. 313(10):2244-54.

Pender, SL., Tickle, SP., Docherty, AJ., Howie, D., Wathen, NC. \& MacDonald, TT. (1997). A major role for matrix metalloproteinases in $\mathrm{T}$ cell injury in the gut. J Immunol. 158(4):1582-90.

Petrof, EO., Ciancio, MJ. \& Chang, EB. (2004). Role and regulation of intestinal epithelial heat shock proteins in health and disease. Chin J Dig Dis. 5(2):45-50.

Pfister, G., Stroh, CM., Perschinka, H., Kind, M., Knoflach, M., Hinterdorfer, P. \& Wick, G. (2005). Detection of HSP60 on the membrane surface of stressed human endothelial cells by atomic force and confocal microscopy. J Cell Sci. 118(Pt 8):1587-94.

Pierce, SK., DeNagel, DC. \& VanBuskirk, AM. (1991). A role for heat shock proteins in antigen processing and presentation. Curr Top Microbiol Immunol. 167:83-92.

Polla, BS. \& Cossarizza, A. (1996). Stress proteins in inflammation. EXS. 77:375-91.

Prahlad, V. \& Morimoto, RI. (2009). Integrating the stress response: lessons for neurodegenerative diseases from C. elegans. Trends Cell Biol. 19(2):52-61.

Pratt, WB., Galigniana, MD., Morishima, Y. \& Murphy, PJ. (2004). Role of molecular chaperones in steroid receptor action. Essays Biochem. 40:41-58.

Qiao, SW., Sollid, LM. \& Blumberg, RS. (2009). Antigen presentation in celiac disease. Curr Opin Immunol. 21(1):111-7.

Quintana, FJ. \& Cohen, IR. (2011). The HSP60 immune system network. Trends Immunol. 32(2):89-95.

Rajaiah, R. \& Moudgil, KD. (2009). Heat-shock proteins can promote as well as regulate autoimmunity. Autoimmun Rev. 8(5):388-93.

Ramos-Arroyo, MA., Feijoó, E., Sánchez-Valverde, F., Aranburu, E., Irisarri, N., Olivera, JE. \& Valiente, A. (2001). Heat-shock protein 70-1 and human leukocyte antigen class II gene polymorphisms associated with celiac disease susceptibility in Navarra (Spain). Hum Immunol. 62(8):821-5.

Reunala ,TL. (2001). Dermatitis herpetiformis. Clin Dermatol. 19(6):728-36.

Richardson, PG., Mitsiades, CS., Laubach, JP., Lonial, S., Chanan-Khan, AA. \& Anderson, KC. (2011). Inhibition of heat shock protein 90 (HSP90) as a therapeutic strategy for the treatment of myeloma and other cancers. Br J Haematol. 152(4):367-79. 
Richter, K., Haslbeck, M. \& Buchner, J. (2010). The heat shock response: life on the verge of death. Mol Cell. 40(2):253-66.

Ritossa, F. (1967). A new puffing pattern induced by temperature shock and DNP in Drosophila. Experientia. 18: 571-573. doi: 10.1007/BF02172188.

Ritossa, F. (1996). Discovery of the heat shock response. Cell Stress Chaperones. 1(2):97-8.

Rivabene, R., Mancini, E. \& De Vincenzi, M. (1999). In vitro cytotoxic effect of wheat gliadinderived peptides on the Caco-2 intestinal cell line is associated with intracellular oxidative imbalance: implications for coeliac disease. Biochim Biophys Acta. 1453(1):152-60.

Rizzuto, R., Pinton, P., Ferrari, D., Chami, M., Szabadkai, G., Magalhães, PJ., Di Virgilio, F. \& Pozzan, T. (2003). Calcium and apoptosis: facts and hypotheses. Oncogene. 22(53):8619-27.

Roberts, RJ., Agius, C., Saliba, C., Bossier, P. \& Sung, YY. (2010). Heat shock proteins (chaperones) in fish and shellfish and their potential role in relation to fish health: a review. J Fish Dis. 33(10):789-801.

Rodolico, V., Tomasello, G., Zerilli, M., Martorana, A., Pitruzzella, A., Gammazza, AM., David, S., Zummo, G., Damiani, P., Accomando, S., Conway de Macario, E., Macario, AJ., Cappello, F. (2010). Hsp60 and Hsp10 increase in colon mucosa of Crohn's disease and ulcerative colitis. Cell Stress Chaperones. 15(6):877-84.

Rodrigo,L. (2009). Investigational therapies for celiac disease. Expert Opin Investig Drugs. 18(12):1865-73.

Rodriguez, F., Arsène-Ploetze, F., Rist, W., Rüdiger, S., Schneider-Mergener, J., Mayer, MP., Bukau, B. (2008). Molecular basis for regulation of the heat shock transcription factor sigma32 by the DnaK and DnaJ chaperones. Mol Cell. 32(3):347-58.

Rokutan, K. (2000). Role of heat shock proteins in gastric mucosal protection. J Gastroenterol Hepatol. 15 Suppl:D12-9.

Ropeleski, MJ., Tang, J., Walsh-Reitz, MM., Musch, MW. \& Chang, EB. (2003). Interleukin11-induced heat shock protein 25 confers intestinal epithelial-specific cytoprotection from oxidant stress. Gastroenterology. 124(5):1358-68.

Rostom, A., Dubé, C., Cranney, A., Saloojee, N., Sy, R., Garritty, C., Sampson, M., Zhang, L., Yazdi, F., Mamaladze, V., Pan, I., MacNeil, J., Mack, D., Patel, D. \& Moher D. (2005). The diagnostic accuracy of serologic tests for celiac disease: a systematic review. Gastroenterology. 128(4 Suppl 1):S38-46.

Rubio-Tapia, A. \& Murray, JA. (2010). Celiac disease. Curr Opin Gastroenterol. 26(2):116-22.

Ryan, MT., Pfanner, N. (2001). Hsp70 proteins in protein translocation. Adv Protein Chem. 59:223-42.

Sartor, RB. (2004). Therapeutic manipulation of the enteric microflora in inflammatory bowel diseases: antibiotics, probiotics, and prebiotics. Gastroenterology. 126(6):162033.

Schirmer, EC., Glover, JR., Singer, MA. \& Lindquist S. (1996). HSP100/Clp proteins: a common mechanism explains diverse functions. Trends Biochem Sci. 21(8):289-96.

Schuppan, D., Dennis, MD. \& Kelly, CP. (2005). Celiac disease: epidemiology, pathogenesis, diagnosis, and nutritional management. Nutr Clin Care. 8(2):54-69.

Schuppan, D., Junker, Y. \& Barisani, D. (2009). Celiac disease: from pathogenesis to novel therapies. Gastroenterology. 137(6):1912-33. 
Schuppan, D. (2000). Current concepts of celiac disease pathogenesis. Gastroenterology. 119(1):234-42.

Setty, M., Hormaza, L. \& Guandalini, S. (2008). Celiac disease: risk assessment, diagnosis, and monitoring. Mol Diagn Ther. 12(5):289-98.

Shang, F. \& Taylor, A. (2011). Ubiquitin-proteasome pathway and cellular responses to oxidative stress. Free Radic Biol Med. 51(1):5-16.

Sharom, FJ. (2008). ABC multidrug transporters: structure, function and role in chemoresistance. Pharmacogenomics. 9(1):105-27.

Sharp, S. \& Workman, P. (2006). Inhibitors of the HSP90 molecular chaperone: current status. Adv Cancer Res. 95:323-48.

Silano, M., Agostoni, C. \& Guandalini, S. (2010). Effect of the timing of gluten introduction on the development of celiac disease. World J Gastroenterol. 16(16):1939-42.

Sims, JD., McCready, J. \& Jay, DG. (2011). Extracellular heat shock protein (Hsp)70 and Hsp90a assist in matrix metalloproteinase-2 activation and breast cancer cell migration and invasion. PLoS One. 6(4):e18848.

Singh, A. \& Grover, A. (2010). Plant Hsp100/ClpB-like proteins: poorly-analyzed cousins of yeast ClpB machine. Plant Mol Biol. 74(4-5):395-404.

Sivaramakrishnan, S., DeGiulio, JV., Lorand, L., Goldman, RD. \& Ridge, KM. (2008). Micromechanical properties of keratin intermediate filament networks. Proc Natl Acad Sci U S A. 105(3):889-94.

Sollid, LM., Jabri, B. (2005). Is celiac disease an autoimmune disorder? Curr Opin Immunol. 17(6):595-600.

Sollid, LM. (2000). Molecular basis of celiac disease. Annu Rev Immunol. 18:53-81.

Soltys, BJ. \& Gupta RS. (1996). Immunoelectron microscopic localization of the 60-kDa heat shock chaperonin protein (Hsp60) in mammalian cells. Exp Cell Res. 222(1):16-27.

Sreedhar, AS., Kalmár, E., Csermely, P. \& Shen, YF. (2004). Hsp90 isoforms: functions, expression and clinical importance. FEBS Lett. 562(1-3):11-5.

Stankiewicz, AR., Lachapelle, G., Foo, CP., Radicioni, SM. \& Mosser, DD. (2005). Hsp70 inhibits heat-induced apoptosis upstream of mitochondria by preventing Bax translocation. J Biol Chem. 280(46):38729-39.

Stetler, RA., Gan, Y., Zhang, W., Liou, AK., Gao, Y., Cao, G. \& Chen, J. (2010). Heat shock proteins: cellular and molecular mechanisms in the central nervous system. Prog Neurobiol. 92(2):184-211.

Stojiljković, V., Todorović, A., Radlović, N., Pejić, S., Mladenović, M., Kasapović, J. \& Pajović, SB. (2007). Antioxidant enzymes, glutathione and lipid peroxidation in peripheral blood of children affected by coeliac disease. Ann Clin Biochem. 44(Pt 6):537-43.

Sukhai, M. \& Piquette-Miller, M. (2000). Regulation of the multidrug resistance genes by stress signals. J Pharm Pharm Sci. 3(2):268-80.

Sun, Y. \& MacRae, TH. (2005). The small heat shock proteins and their role in human disease. FEBS J. 272(11):2613-27.

Suto, R. \& Srivastava, PK. (1995). A mechanism for the specific immunogenicity of heat shock protein-chaperoned peptides. Science. 269(5230):1585-8.

Szaflarska-Poplawska, A., Siomek, A., Czerwionka-Szaflarska, M., Gackowski, D., Rózalski, R., Guz, J., Szpila, A., Zarakowska, E. \& Olinski, R. (2010). Oxidatively damaged 
DNA/oxidative stress in children with celiac disease. Cancer Epidemiol Biomarkers Prev. 19(8):1960-5.

Szebeni, B., Veres, G., Dezsofi, A., Rusai, K., Vannay, A., Bokodi, G., Vásárhelyi, B., Korponay-Szabó, IR., Tulassay, T. \& Arató, A. (2007). Increased mucosal expression of Toll-like receptor (Toll-like receptor)2 and Toll-like receptor4 in coeliac disease. J Pediatr Gastroenterol Nutr. 45(2):187-93.

Sziksz, E., Veres, G., Vannay, A., Prókai, A., Gál, K., Onody, A., Korponay-Szabó, IR., Reusz, G., Szabó, A., Tulassay, T., Arató, A. \& Szebeni, B. (2010). Increased heat shock protein 72 expression in celiac disease. J Pediatr Gastroenterol Nutr. 51(5):573-8.

Takada, M., Otaka, M., Takahashi, T., Izumi, Y., Tamaki, K., Shibuya, T., Sakamoto, N., Osada, T., Yamamoto, S., Ishida, R., Odashima, M., Itoh, H. \& Watanabe, S. (2010). Overexpression of a $60-\mathrm{kDa}$ heat shock protein enhances cytoprotective function of small intestinal epithelial cells. Life Sci. 86(13-14):499-504.

Takeda, K., Kaisho, T. \& Akira, S. (2003). Toll-like receptors. Annu Rev Immunol. 21:335-76.

Tanaka, K. \& Mizushima, T. (2009). Protective role of heat shock factor1 and HSP70 against gastrointestinal diseases. Int J Hyperthermia. 25(8):668-76.

Tanaka, K., Tanaka, Y., Namba, T., Azuma, A. \& Mizushima T. (2010). Heat shock protein 70 protects against bleomycin-induced pulmonary fibrosis in mice. Biochem Pharmacol. 80(6):920-31.

Tanguay, RM., Wu, Y. \& Khandjian, EW. (1993). Tissue-specific expression of heat shock proteins of the mouse in the absence of stress. Dev Genet. 14(2):112-8.

Tao, Y., Drabik, KA., Waypa, TS., Musch, MW., Alverdy, JC., Schneewind, O., Chang, EB. \& Petrof, EO. (2006). Soluble factors from Lactobacillus GG activate MAPKs and induce cytoprotective heat shock proteins in intestinal epithelial cells. Am J Physiol Cell Physiol. 290(4):C1018-30.

Tashiro, S. (2009). Mechanism of liver regeneration after liver resection and portal vein embolization (ligation) is different? J Hepatobiliary Pancreat Surg. 16(3):292-9.

Thomas, JG. \& Baneyx, F. (1998). Roles of the Escherichia coli small heat shock proteins IbpA and $\mathrm{IbpB}$ in thermal stress management: comparison with $\mathrm{ClpA}, \mathrm{ClpB}$, and HtpG In vivo. J Bacteriol180(19):5165-72.

Timperio, AM., Egidi, MG. \& Zolla, L. (2008). Proteomics applied on plant abiotic stresses: role of heat shock proteins (HSP). J Proteomics. 71(4):391-411.

Tiroli-Cepeda, AO. \& Ramos, CH. (2011). An overview of the role of molecular chaperones in protein homeostasis. Protein Pept Lett. 18(2):101-9.

Toivola, DM., Strnad, P., Habtezion, A. \& Omary, MB. (2010). Intermediate filaments take the heat as stress proteins. Trends Cell Biol. 20(2):79-91.

Truettner, JS., Hu, K., Liu, CL., Dietrich, WD. \& Hu, B. (2009). Subcellular stress response and induction of molecular chaperones and folding proteins after transient global ischemia in rats. Brain Res. 1249:9-18.

Trynka, G., Wijmenga, C. \& van Heel, DA. (2010). A genetic perspective on coeliac disease. Trends Mol Med. 16(11):537-50.

Tsan, MF. \& Gao, B. (2004). Endogenous ligands of Toll-like receptors. J Leukoc Biol. 76(3):514-9.

Tsan, MF. \& Gao, B. (2009). Heat shock proteins and immune system. J Leukoc Biol. 85(6):90510. 
Tsapara, A., Matter, K. \& Balda, MS. (2006). The heat-shock protein Apg-2 binds to the tight junction protein ZO-1 and regulates transcriptional activity of ZONAB. Mol Biol Cell. 17(3):1322-30.

Turner, JR. (2009). Intestinal mucosal barrier function in health and disease. Nat Rev Immunol. 9(11):799-809.

Van Montfort, R., Slingsby, C. \& Vierling, E. (2001). Structure and function of the small heat shock protein/alpha-crystallin family of molecular chaperones. Adv Protein Chem. 59:105-56.

van Straaten, EA., Koster-Kamphuis, L., Bovee-Oudenhoven, IM., van der Meer, R. \& Forget, PP. (1999). Increased urinary nitric oxide oxidation products in children with active coeliac disease. Acta Paediatr. 88(5):528-31.

Vigh, L., Nakamoto, H., Landry, J., Gomez-Munoz, A., Harwood, JL. \& Horvath, I. (2007). Membrane regulation of the stress response from prokaryotic models to mammalian cells. Ann N Y Acad Sci. 1113:40-51. Epub 2007 Jul 26.

Virta, LJ., Kaukinen, K. \& Collin, P. (2009). Incidence and prevalence of diagnosed coeliac disease in Finland: Results of effective case finding in adults. Scand J Gastroenterol. 44(8):933-8.

Volloch, V., Gabai, VL., Rits, S., Force, T. \& Sherman, MY. (2000). HSP72 can protect cells from heat-induced apoptosis by accelerating the inactivation of stress kinase JNK. Cell Stress Chaperones. 5(2):139-47.

von Mikecz, A., Chen, M., Rockel, T. \& Scharf, A. (2008). The nuclear ubiquitin-proteasome system: visualization of proteasomes, protein aggregates, and proteolysis in the cell nucleus. Methods Mol Biol. 463:191-202.

Wagner, OI., Rammensee, S., Korde, N., Wen, Q., Leterrier, JF. \& Janmey, PA. (2007). Softness, strength and self-repair in intermediate filament networks. Exp Cell Res. 313(10):2228-35.

Watson, AJ. (1995). Necrosis and apoptosis in the gastrointestinal tract. Gut. 37(2):165-7.

Welker, S., Rudolph, B., Frenzel, E., Hagn, F., Liebisch, G., Schmitz, G., Scheuring, J., Kerth, A., Blume, A. \& Weinkauf, S., Haslbeck, M., Kessler, H. \& Buchner, J. (2010). Hsp12 is an intrinsically unstructured stress protein that folds upon membrane association and modulates membrane function. Mol Cell. 39(4):507-20.

Westerheide, SD., Anckar, J., Stevens, SM Jr., Sistonen, L. \& Morimoto, RI. (2009). Stressinducible regulation of heat shock factor 1 by the deacetylase SIRT1. Science. 323(5917):1063-6.

Wong, HR. \& Wispé, JR. (1997). The stress response and the lung. Am J Physiol. 273(1 Pt 1):L1-9.

Xanthoudakis, S., Roy, S., Rasper, D., Hennessey, T., Aubin, Y., Cassady, R., Tawa, P., Ruel, R., Rosen, A. \& Nicholson, DW. (1999). Hsp60 accelerates the maturation of procaspase-3 by upstream activator proteases during apoptosis. EMBO J. 18(8):2049-56.

Yang, PC., He, SH. \& Zheng, PY. (2007). Investigation into the signal transduction pathway via which heat stress impairs intestinal epithelial barrier function. J Gastroenterol Hepatol. 22(11):1823-31.

Yeboah, FA. \& White, D. (2001). AlphaB-crystallin expression in celiac disease - a preliminary study. Croat Med J. 42(5):523-6.

Young, JC. (2010). Mechanisms of the Hsp70 chaperone system. Biochem Cell Biol. 88(2):291300. 
Zitka, O., Kukacka, J., Krizkova, S., Huska, D., Adam, V., Masarik, M., Prusa, R. \& Kizek, R. (2010). Matrix metalloproteinases. Curr Med Chem. 17(31):3751-68. 
(C) 2012 The Author(s). Licensee IntechOpen. This is an open access article distributed under the terms of the Creative Commons Attribution 3.0 License, which permits unrestricted use, distribution, and reproduction in any medium, provided the original work is properly cited. 